\title{
The Capacity of African Research Institutions to Respond to HIV/M. tuberculosis Co-Infection
}

\author{
Andrew Charman ${ }^{1}$, Gerhard Walzl ${ }^{2}$ and Wolfgang Preiser ${ }^{*}, 3$
}

\author{
${ }^{I}$ Sustainable Livelihoods Foundation, Cape Town, South Africa; ${ }^{2}$ Department of Science and Technology/National \\ Research Foundation Centre of Excellence in Biomedical TB Research, Faculty of Health Sciences, Department of \\ Biomedical Sciences, Stellenbosch University, ${ }^{3}$ Division of Medical Virology, Department of Pathology, Stellenbosch \\ University, Cape Town, South Africa
}

\begin{abstract}
The paper reports on an investigation undertaken for the Network for European/ICPC cooperation in the field of AIDS and TB (EUCO-Net) into the state of biomedical research on the HIV/AIDS and Mycobacterium tuberculosis (MTB)/tuberculosis (TB) within 13 selected Sub-Saharan African countries. The case countries were Botswana, Central African Republic, Ethiopia, Gambia, Gabon, Kenya, Malawi, Mozambique, Senegal, South Africa, Uganda, Zambia and Zimbabwe. An important objective of the research was to document the extent of linkages between HIV/AIDS and TB research endeavours within these countries to address co-infection. The study examines five aspects of current research in these fields. First, it considers individual country demographic and epidemiological status. Second, it examines the scope and costs of diagnostic services for these diseases. Third, it considers inter-cultural sensitivities that positively or negatively impact on (or influence) biomedical research in the case countries. Fourth, it identifies the extent of funding for basic science research and details the main institutional funders and recipients of funding. Fifth, it details the scale of medical studies with respect to the two diseases, identifying the scope of research activities within the case countries, the nature of the funding and research partners. The research concludes that African institutions can significantly contribute towards addressing the scientific challenges needed to advance diagnostics, pioneer new drugs and develop vaccines, but only if they receive a significantly higher injection of funding. South African institutions are well positioned (scientifically) to lead research within the African context, having the human capacity to conduct research and benefiting from supportive state institutions.
\end{abstract}

Keywords: Sub-Saharan Africa, co-infection, tuberculosis, HIV, biomedical research funding.

\section{INTRODUCTION}

This report details the main findings of research that was undertaken in support of the Sub-Saharan African (SSA) report, for the Network for European/ICPC cooperation in the field of acquired immunodeficiency syndrome (AIDS) and tuberculosis (TB) (EUCO-Net) project on global cooperation in the field of human immunodeficiency virus (HIV) and Mycobacterium tuberculosis (MTB). The overriding study objective was to identify the 'state of art' in African biomedical research efforts and the institutional linkages between HIV/AIDS and TB research endeavours. This paper presents the approach and methodology used to obtain the data to compile the original report on the situation in SSA. The document details the main findings and strategic recommendations for strengthening research collaboration. An important outcome of the research is our findings on the provision of funding towards biomedical research on HIV/AIDS and MTB/TB to African institutions in the 13 selected case countries. The objective was to highlight broad trends in funding to identify leading institutions and the state of African research capacity. The report concludes on the need to bolster funding to African institutions and to develop strategic clusters of expertise and programme co-ordination within and between African countries to advance research on the diseases and co-infection.

*Address correspondence to this author at the Division of Medical Virology, Department of Pathology, Stellenbosch University, Cape Town, South Africa; Tel: +27 21938 9353; Fax: +27 21938 9361;

E-mail: preiser@sun.ac.za

\section{BACKGROUND}

There is growing concern within the global scientific community that current approaches towards tackling the dual epidemic of AIDS and TB are not succeeding. The impact of these diseases has steadily increased and co-infection now presents an added challenge to the impact of research and medicine to reduce human morbidity and mortality. It is estimated that approximately one quarter of the global population infected with HIV are co-infected with MTB. The combined threat posed by these diseases has resulted in a heightened awareness around preventative strategies and greater commitment and increased funding for research. Yet there remains concern that the response to the dual epidemic has not been tackled in an integrated manner. There is much anecdotal evidence that national AIDS and TB programmes continue to work in isolation from each other, whilst there is still very limited collaboration among the scientists dedicated to studying these pathogens outside their respective disciplines.

EUCO-Net seeks to contribute towards promoting integrated research on the dual epidemic and fostering collaboration between European institutions and international cooperation partner countries (ICPC). In support of these objectives, EUCO-Net had initiated a collaborative research and information dissemination project involving European institutions and partners in Latin America, Russia, South Asia (India) and Southern Africa. The initiative had three central objectives: first, to produce detailed country reports on the epidemiological status and 
research capacity/orientation in the partner countries; second, to workshop the findings with selected experts to delineate an appropriate strategy for advancing future research and collaboration; and third, to develop and disseminate the findings through an AIDS/TB Roadmap tool. EUCO-Net partnered with Stellenbosch University (SUN) in this action.

\section{TERMS OF REFERENCE}

The overall objectives of the EUCO-Net research project were to address the following topics in the context of the SSA case.

- The epidemiological status of HIV/AIDS and TB/MTB,

- The state of the art of research,

- Existing research projects,

- Medical treatment standards and protocols,

- Diagnostic standards,

- Scientific challenges and topics for further research,

- Existing national and international funding programmes supporting research in the case countries.

The research was structured to meet the requirements of a questionnaire tool. The tool was designed to capture the research findings on country demographic status, the basic epidemiology of HIV/AIDS and MTB/TB, diagnostic standards and costs, and case specific inter-cultural sensitivities. A further questionnaire required each regional team to identify the ten key scientific challenges for the future. These challenges were identified through dialogue with scientific leaders at SUN and their collaborating partners in South Africa.

\section{SCOPE}

\section{Country Focus}

At the research inception meeting it was proposed and subsequently agreed that the SSA report would include the following 13 countries:

$\begin{array}{ll}\text { i. } & \text { Botswana } \\ \text { ii. } & \text { Central African Republic (CAR) } \\ \text { iii. } & \text { Ethiopia } \\ \text { iv. } & \text { Gambia } \\ \text { v. } & \text { Gabon } \\ \text { vi. } & \text { Kenya } \\ \text { vii. } & \text { Malawi } \\ \text { viii. } & \text { Mozambique } \\ \text { ix. } & \text { Senegal } \\ \text { x. } & \text { South Africa } \\ \text { xi. } & \text { Uganda } \\ \text { xii. } & \text { Zambia } \\ \text { xiii. } & \text { Zimbabwe }\end{array}$

The rationale for the selection of these countries was based on four considerations: first, geo-political and socio- cultural considerations, reflective of the diversity of peoples and cultural environments within SSA; second, the country prevalence of HIV/AIDS and TB, with preference to regions with the highest prevalence rates in both diseases; third, the apparent intensity of research effort and funding allocation; fourth, institutional linkages and collaboration with SUN researchers.

\section{Time Frame}

The analysis considers biomedical research in AIDS/HIV and MTB/TB led by African institutions in the period since 2005. In our examination of basic epidemiological trends, we endeavoured to present the latest data accessible from global (multilateral) institutions. At the time of conducting the research, in 2008, the most recent data was for 2007. The specific methods utilised to assemble the various data sets for the respective research components are discussed separately in each section.

In our examination of research in the case countries, we considered all projects/programmes initiated from 1 January 2005. The cut-off included projects that were underway on the 1 January 2005 as well as projects that had commenced after that time. Similarly, in our assessment of the provision of research grants, we considered all awards provided to African institutions in the timeframe 1 January 2005 to 31 December 2008.

\section{Topic Scope}

The investigation was restricted to the topic of biomedical research in the fields of HIV/AIDS, MTB/TB and HIV-MTB co-infection. The scope included basic scientific research, clinical and vaccine trials and diagnostics research. The scope excluded non-biomedical research in these fields, including behavioural studies, epidemiological studies, and actions primarily directed at teaching, training or institutional capacity building which would not directly enhance biomedical research. This distinction was not always clear cut. In our investigation of research funding, it was not always possible to distinguish between purely biomedical and behavioural/epidemiological components or to identify the specific allocation to biomedical research in large funding awards towards institutional capacity building programmes.

\section{DEMOGRAPHIC ANALYSIS}

\section{Method}

The research considered the most recent demographic data from two sources: i) the United Nationals Statistics Division's Demographic Year Book (2006) [1] and ii) the Population Reference Bureau's 2008 World Population Data Sheet (2010) [2]. The Demographic Year Book provided data on population growth forecasts for the period 2005-2010. The World Population Data Sheet was utilised to report on aggregate populations, the age structure and life expectancy for each case country.

\section{Outcome}

The demographic data highlights the relatively underdeveloped livelihoods status of the SSA continent and the huge challenges it faces to provide health care to a population that is growing rapidly and is characterised by a 
high dependency ratio (proportion of young and old to working age adults). The data is shown in Table $\mathbf{1}$.

The 13 case countries have a combined population of 299 million. These countries thus make up approximately $31 \%$ of the continent's population of 943 million. Africa has a comparatively fast growing population with a crude annual birth rate of 39 persons per 1000; a figure that contrast with the world average of 20 persons per 1000 . The annual rate of population increase for SSA in the period 2000-2010 is estimated at $2.2 \%$, one percent higher than the world average. The continent's population age structure is highly skewed with more than $41 \%$ of the sub-continent's population under 15 years old. The life expectancy at birth across all SSA countries is 53.9 years. Women in the case countries are likely to outlive men with 56 years compared to 52 years. The crude annual death rate in SSA is 13 persons per 1000 against the world average of 9 per 1000 .

Against the overall demographic profile of SSA, the case countries exhibit some significant variation. The populations of Botswana, Gabon, Gambia and South Africa are significantly urbanized with more than half their respective populations residing in towns and cities. The trend towards urbanization is expected to intensify over the next decade. The countries with high levels of urbanisation also have a correspondingly higher level of life expectation, with the exception of Kenya and Senegal (highest among the case countries), where improved life expectation can be attributed to the quality of primary health care services and low level of disease burden.

Poor countries, especially the Least Developed Countries (LDC) group, namely Central African Republic, Gambia, Ethiopia, Malawi, Mozambique, Uganda and Zambia, have predominantly rural populations and low life expectancy. Botswana, South Africa and Gabon, the three case countries with the highest per capita income, have the lowest crude birth rates and hence a much lower proportion of the population under 15 years. Central African Republic (19 per 1000), Mozambique (20 per 1000), Zambia (22 per 1000) and Zimbabwe (21 per 1000) respectively have an annual death rate more than double the world average.

\section{BASIC EPIDEMIOLOGICAL ANALYSIS}

\section{Method}

The research examined the most up-to-date epidemiological data released by the World Health Organisation (WHO) and Joint United Nations Programme on HIV/AIDS (UNAIDS). These sources were chosen for two reasons. Firstly, the researchers found that national institutions within the case countries either have no accessible public health knowledge systems, or where these systems exist (for example in the South African case), they do not present current knowledge, but data that has long since been superseded by information available from global institutions. Second, the data released by the WHO and UNAIDS, which the researchers drew upon, is comprehensive and permits cross-country and global comparison.

Epidemiological data on HIV/AIDS was obtained from the UNAIDS/WHO 2008 Report on the global AIDS epidemic (July 2008), Annex 1 [6]. The data on TB and multidrug resistant (MDR) TB was obtained from the $\boldsymbol{W H O}$ Report on Tuberculosis, 2008, Annexes 1-13 [4]. Data from both datasets was downloaded as spreadsheets, thus enabling the researchers to undertake a series of independent calculations. Although the WHO Report on Tuberculosis examines the challenge of extensively drug resistant (XDR) $\mathrm{TB}$, the report does not provide country specific data on the level of incidence or prevalence. The researchers therefore identified public health and media information sources detailing the occurrence of XDR in specific case countries where such information was accessible from open-access web sources. The validity of the data on XDR is subject to correction and may not fully capture the epidemiology in countries with weak diagnostic and information management systems, such as Mozambique where incidence could be significantly higher.

The data we obtained from the WHO and UNAIDS datasets is subject to the following qualifications:

- $\quad$ Observed cases of HIV+ = midpoint estimate, HIV prevalence data. Data was disaggregated between 014 years and $>15$ years.

- $\quad$ AIDS population $=$ midpoint estimate, total number of person with advanced HIV disease requiring antiretroviral therapy (ART), estimated using the UNAIDS/WHO methodology.

- $\quad$ Percentage of HIV + persons on ART = calculated on the basis of the number of persons with advanced HIV disease receiving ART of the total population requiring ART. Data was disaggregated between 0-14 years and $>15$ years.

- $\quad$ Therapy costs $=$ costs of care and treatment including ART. The cost of treatment in Euro was calculated, using average annual exchange rates.

- $\quad$ New TB cases $=$ notified TB cases, directly observed therapy-short course (DOTS) and Non-DOTS.

- New MDR cases = calculated on the basis of the percentage of new TB cases. In some case countries, the data refers only to laboratory confirmed cases (indicated in the questionnaire).

- $\quad$ Percentage of TB treatment success = new smearpositive cases, DOTS.

\section{Outcome}

\section{HIV/AIDS Epidemiology}

The data reveals a strongly unequal geographic distribution in the HIV/AIDS pandemic. Adult prevalence is highest in Southern Africa (Botswana 23\% and South Africa $18 \%$ ), though also high in central/southern Africa (Zimbabwe $15 \%$, Zambia 15\%, Malawi 11\%, and Mozambique $12 \%$ ), yet relatively low in West Africa (Senegal 1\% and Gambia 0.9\%) and North East Africa (Ethiopia 2.1\%). The central region of the continent reports levels of prevalence, from west to east, that fall between the extremes of the northern and southern case countries (Gabon $5.9 \%$, Central African Republic 6.3\%, and Uganda 5.4\%). 
Table 1. SSA Case Countries, Demographic Profiles [2, 3]

\begin{tabular}{|c|c|c|c|c|c|c|c|c|c|c|c|c|c|}
\hline & 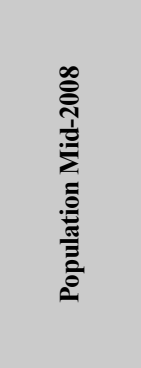 & 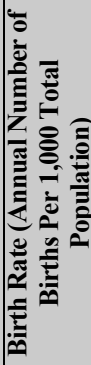 & 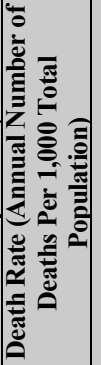 & 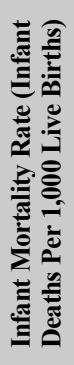 & 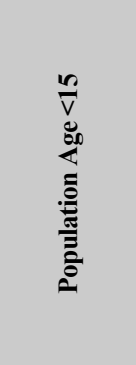 & 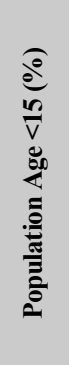 & 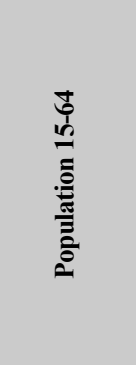 & 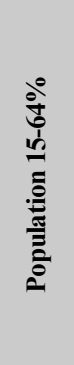 & 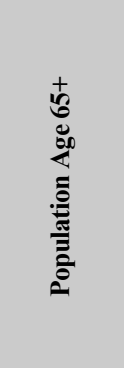 & 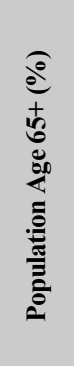 & 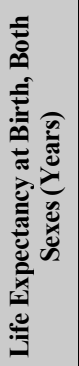 & 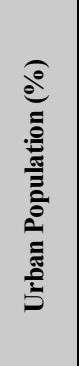 & 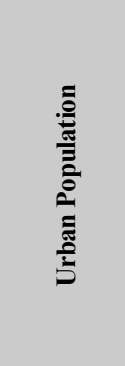 \\
\hline Year & 2008 & 2008 & 2008 & 2008 & 2008 & 2008 & 2008 & 2008 & 2008 & 2008 & 2008 & 2008 & 2008 \\
\hline Botswana & $1,842,000$ & 24 & 14 & 44 & 695,000 & 38 & $1,320,000$ & 72 & 61,000 & 3 & 49 & 57 & $1,057,000$ \\
\hline $\begin{array}{l}\text { Central African } \\
\text { Republic }\end{array}$ & $4,435,000$ & 38 & 19 & 102 & $1,894,000$ & 43 & $4,755,000$ & 107 & 173,000 & 4 & 43 & 38 & $1,685,000$ \\
\hline Ethiopia & $79,087,000$ & 40 & 15 & 77 & $33,849,000$ & 43 & $45,301,000$ & 57 & $2,214,000$ & 3 & 49 & 16 & $13,010,000$ \\
\hline Gabon & $1,350,000$ & 27 & 12 & 58 & 485,000 & 36 & 916,000 & 68 & 63,000 & 5 & 57 & 84 & $1,129,000$ \\
\hline Gambia & $1,559,000$ & 38 & 11 & 93 & 655,000 & 42 & $1,777,000$ & 114 & 51,000 & 3 & 58 & 54 & 840,000 \\
\hline Kenya & $37,954,000$ & 40 & 12 & 77 & $15,941,000$ & 42 & $22,381,000$ & 59 & 873,000 & 2 & 53 & 19 & $7,325,000$ \\
\hline Malawi & $13,630,000$ & 48 & 16 & 80 & $6,215,000$ & 46 & $7,945,000$ & 58 & 368,000 & 3 & 46 & 17 & $2,363,000$ \\
\hline Mozambique & $20,387,000$ & 41 & 20 & 108 & $8,685,000$ & 43 & $12,235,000$ & 60 & 530,000 & 3 & 43 & 29 & $5,953,000$ \\
\hline Senegal & $12,688,000$ & 39 & 10 & 61 & $5,557,000$ & 44 & $9,209,000$ & 73 & 533,000 & 4 & 62 & 41 & $5,177,000$ \\
\hline South Africa & $48,315,000$ & 23 & 15 & 45 & $15,557,000$ & 32 & $33,488,000$ & 69 & $2,078,000$ & 4 & 50 & 59 & $28,641,000$ \\
\hline Uganda & $29,194,000$ & 48 & 16 & 76 & $14,422,000$ & 49 & $15,065,000$ & 52 & 730,000 & 3 & 48 & 13 & $3,883,000$ \\
\hline Zambia & $12,197,000$ & 43 & 22 & 100 & $5,635,000$ & 46 & $7,034,000$ & 58 & 293,000 & 2 & 38 & 37 & $4,537,000$ \\
\hline Zimbabwe & $13,481,000$ & 31 & 21 & 60 & $5,325,000$ & 40 & $8,628,000$ & 64 & 472,000 & 4 & 40 & 37 & $5,024,000$ \\
\hline
\end{tabular}

\begin{tabular}{|c|c|c|c|c|c|c|c|c|c|}
\hline & 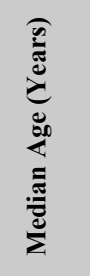 & 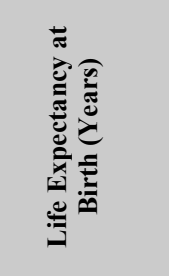 & 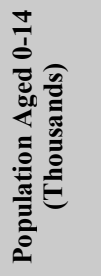 & 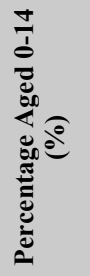 & 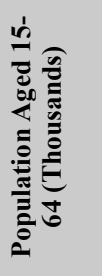 & 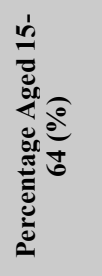 & 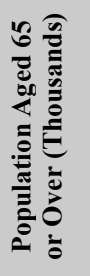 & 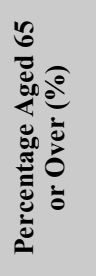 & 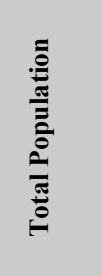 \\
\hline Year & 2010 & 2005-2010 & 2010 & 2010 & 2010 & 2010 & 2010 & 2010 & 2010 \\
\hline Botswana & 22.8 & 54.9 & 651 & 32.9 & 1250 & 63.2 & 76 & 3.9 & 1,977 \\
\hline Central African Republic & 19.5 & 46.9 & 1818 & 40.3 & 2514 & 55.8 & 175 & 3.9 & 4,507 \\
\hline Ethiopia & 18 & 55 & 36682 & 43.2 & 45567 & 53.6 & 2727 & 3.2 & 84,976 \\
\hline Gabon & 21.6 & 60.3 & 534 & 35.6 & 902 & 60.1 & 65 & 4.3 & 1,501 \\
\hline Gambia & 18.8 & 55.8 & 737 & 42.1 & 964 & 55.1 & 50 & 2.9 & 1,751 \\
\hline Kenya & 18.4 & 54.2 & 17500 & 42.8 & 22287 & 54.5 & 1075 & 2.6 & 40,862 \\
\hline Malawi & 16.8 & 52.9 & 7203 & 45.9 & 7999 & 51 & 490 & 3.1 & 15,692 \\
\hline Mozambique & 17.9 & 47.8 & 10268 & 43.9 & 12367 & 52.8 & 770 & 3.3 & 23,405 \\
\hline Senegal & 18 & 55.4 & 5572 & 43.3 & 6982 & 54.3 & 307 & 2.4 & 12,861 \\
\hline South Africa & 24.9 & 51.6 & 15302 & 30.3 & 32863 & 65.1 & 2327 & 4.6 & 50,492 \\
\hline Uganda & 15.6 & 52.4 & 16465 & 48.7 & 16474 & 48.7 & 857 & 2.5 & 33,796 \\
\hline Zambia & 16.8 & 45.2 & 6123 & 46.2 & 6730 & 50.8 & 404 & 3 & 13,257 \\
\hline Zimbabwe & 19 & 44.1 & 4990 & 39.5 & 7132 & 56.4 & 522 & 4.1 & 12,644 \\
\hline
\end{tabular}


Individual UNAIDS country reports indicate that prevalences are highest among urban populations in all countries, apart from those in Southern African, and in South Africa in particular where the disease burden is highest among the country's rural population. In Southern Africa, HIV prevalence in adults (15-49 years) has worsened since 2001, whereas the data suggest that rates of prevalence for the entire population have stabilized and have begun to fall in other case country regions ${ }^{1}$ (see Fig. 1). The data shows that there are noticeable country differences in the prevalence between men and women, with younger women more severely affected then their male age counterparts. The difference in the southern African countries is extreme (see Fig. 2) and highlights the importance of behavioural interventions which empower young women.

The data on the number of people with AIDS and ART situation is presented in Table 2. In the 13 case countries there were 3.9 million persons in 2007 with an advanced stage of HIV disease (AIDS). Of this population, only $35 \%$ were receiving ART. The estimated percentage of persons with AIDS receiving ART varies significantly between the case countries, with Botswana performing best with 79\%, whilst Zimbabwe and the Gambia performed worst with only $18 \%$ on ART. In South Africa, despite the government's recent programme to broaden access to ART, only $56 \%$ of persons with AIDS have access to it. The data indicates that 961,600 persons died as a direct result of AIDS in these countries in 2007, with over $1 / 3$ of these deaths occurring in South Africa. WHO estimate that at present (2007) 4.1 million persons in the case countries require ART.

The data on public health expenditure to address the pandemic is sketchy. The case countries spend collectively about $€ 1.2$ billion annually to combat the disease, with the bulk of funds provided by donors. The data on therapy costs (clinical care, drugs and laboratory tests ) is incomplete with no data for Ethiopia, Mozambique, Senegal, Zambia and Zimbabwe. Among the remaining countries, the daily cost of therapy per person per day varies from $€ 3.69$ (Botswana) to $€ 0.30$ (Gambia) (average $€ 1.59$ ). The cost of therapy in South Africa is unknown but is thought to be similar to the Botswana figure. It is thought that the figures for these other case countries possibly under-represents the actual costs of providing ART to HIV-infected persons in the public sector.

The UNAIDS/WHO report does not provide data on treatment success. The research was only able to obtain reliable data for South Africa, from the National Institute of Communicable Diseases (NICD)/National Health Laboratory Service (NHLS) Communicable Diseases Surveillance Bulletin [5]. Treatment success was determined on the basis of the percentage of tests with undetectable viral load result $(589,352 / 2$ tests) of the total number of viral load tests done in $2008(1,003,218 / 2$ tests). While these results suggest that the current level of treatment success is approximately $58 \%$ this is only a rough estimate, as a number of confounding factors are not accounted for.

${ }^{1}$ The Zimbabwean data may be misleading and inaccurate, given the collapse in its public service sector since 2001 .

\section{TB Epidemiology}

WHO data on TB, presented in Table $\mathbf{3}$, shows that the disease burden is more widely distributed throughout the continent than HIV/AIDS and can be less easily described in geographical terms. TB has affected more than 1.4 million persons (in all forms) in the 13 case countries; the number of affected persons has doubled since 1990 (prevalence $711,060)$ with indications that this trend is likely to continue as co-infection worsens. There are currently more than 3.7 million persons with TB (all forms) in SSA. TB incidence has increased notably over the period 1990-2007, especially in Southern Africa and East Africa (Ethiopia and Kenya) as illustrated in Fig. (3).

Prevalence in the case countries is highest (in crude numbers) in six countries: Ethiopia $(481,175)$, South Africa $(335,911)$, Uganda $(131,636)$, Kenya $(119,842)$, Mozambique $(107,752)$ and Zimbabwe $(95,298)$. Within the Southern and Central African countries, a high proportion of TB cases are co-infected with HIV/AIDS. Co-infection is notable in the case of South Africa $73 \%$ in incident TB cases, all forms), Zimbabwe (70\% in incident TB cases, all forms), Zambia (69\% in incident TB cases, all forms), Botswana (68\% in incident TB cases, all forms), and Malawi (68\% of incident TB cases, all forms). Co-infection is reported to affect a much smaller proportion of TB case incidence in Ethiopia (19\%), Gambia (11.5\%) and Senegal (12.5\%); these figures correlate with the much lower levels of HIV prevalence in these countries.

There were 292,898 new sputum smear positive cases of TB in the case countries in 2007. Of all new cases, however, $49 \%(283,474)$ either tested negative or the sputum result is unknown. In the South African case, the figure for no result is $44 \%$. These figures highlight the inadequacy of sputum testing as a front line diagnostic tool.

TB accounted for the death of 349,744 persons in the case countries in 2007; one third of these deaths occurred in South Africa. In the broader SSA context, TB resulted in the mortality of 734,891 persons in that year. Data on treatment success is limited. WHO reports on the treatment success of new, smear positive cases, by DOTS. The data shows that approximately $53 \%$ of new cases of pulmonary TB undergo treatment, all case countries considered, of which $67 \%$ were successfully treated. Treatment success was highest in Zambia ( $85 \%$ success) and lowest in Gabon (46\%); South Africa, with the greatest number of individuals under treatment and $100 \%$ of new pulmonary cases placed on treatment, reported a success rate of $74 \%$. The high treatment success reported in Ethiopia, Zambia, Kenya and Zambia should be cautiously interpreted and reflects more accurately the relatively low number of new cases undergoing treatment.

The WHO data reports a total of 37,312 cases of MDR in all forms of TB for the 13 case countries. The report provides an estimation of the percentage of new cases (all forms) likely to develop MDR TB in each country. The highest percentage occurs in Mozambique (4\%), with the other Southern African countries estimated to be half this figure $(2 \%)$. These figures indicate that there were 13,194 new MDR TB cases in all case countries in 2007. Data on 


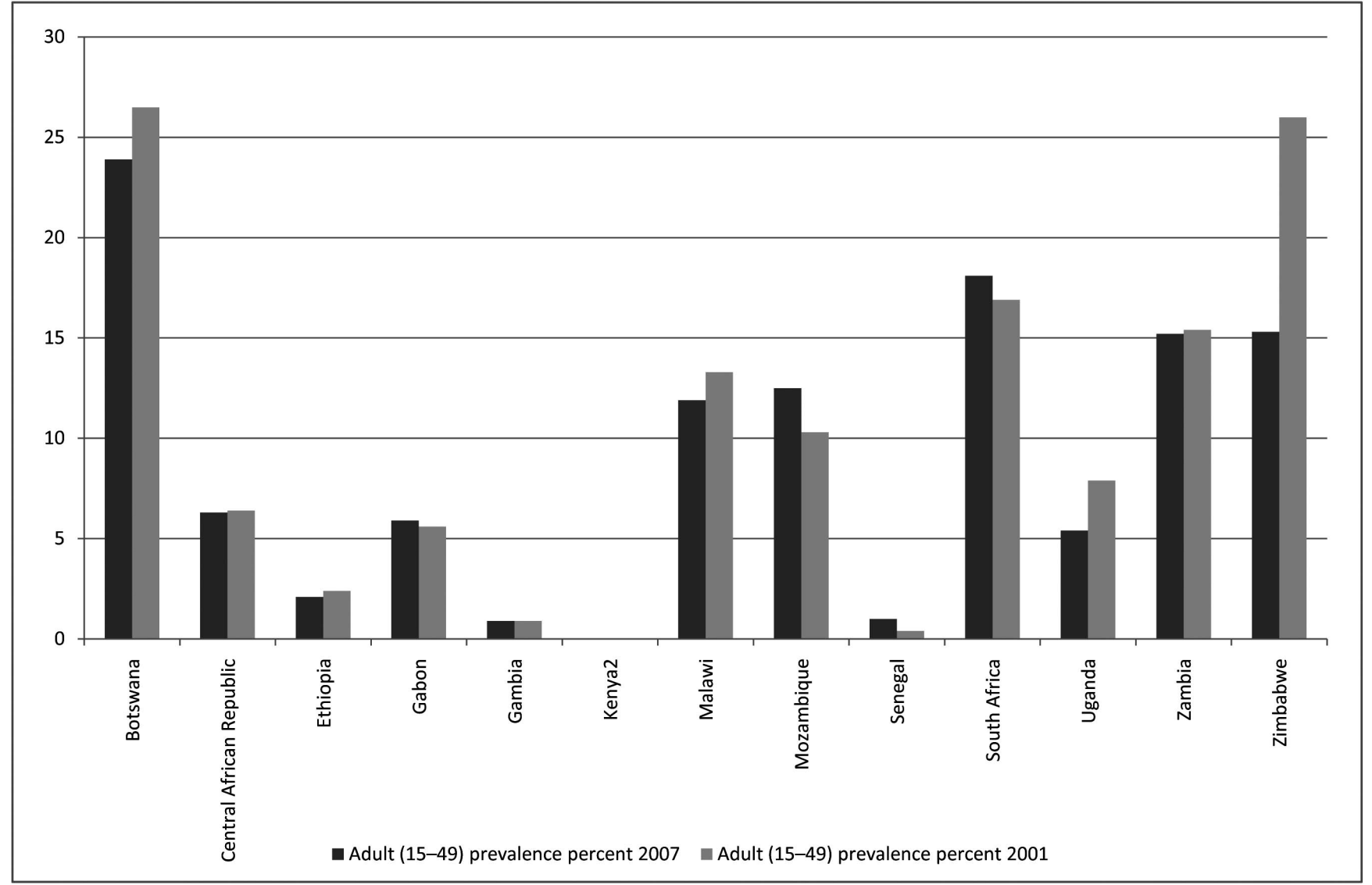

Source [6].

Fig. (1). Adult (15-49) HIV prevalence, 2001 and 2007.

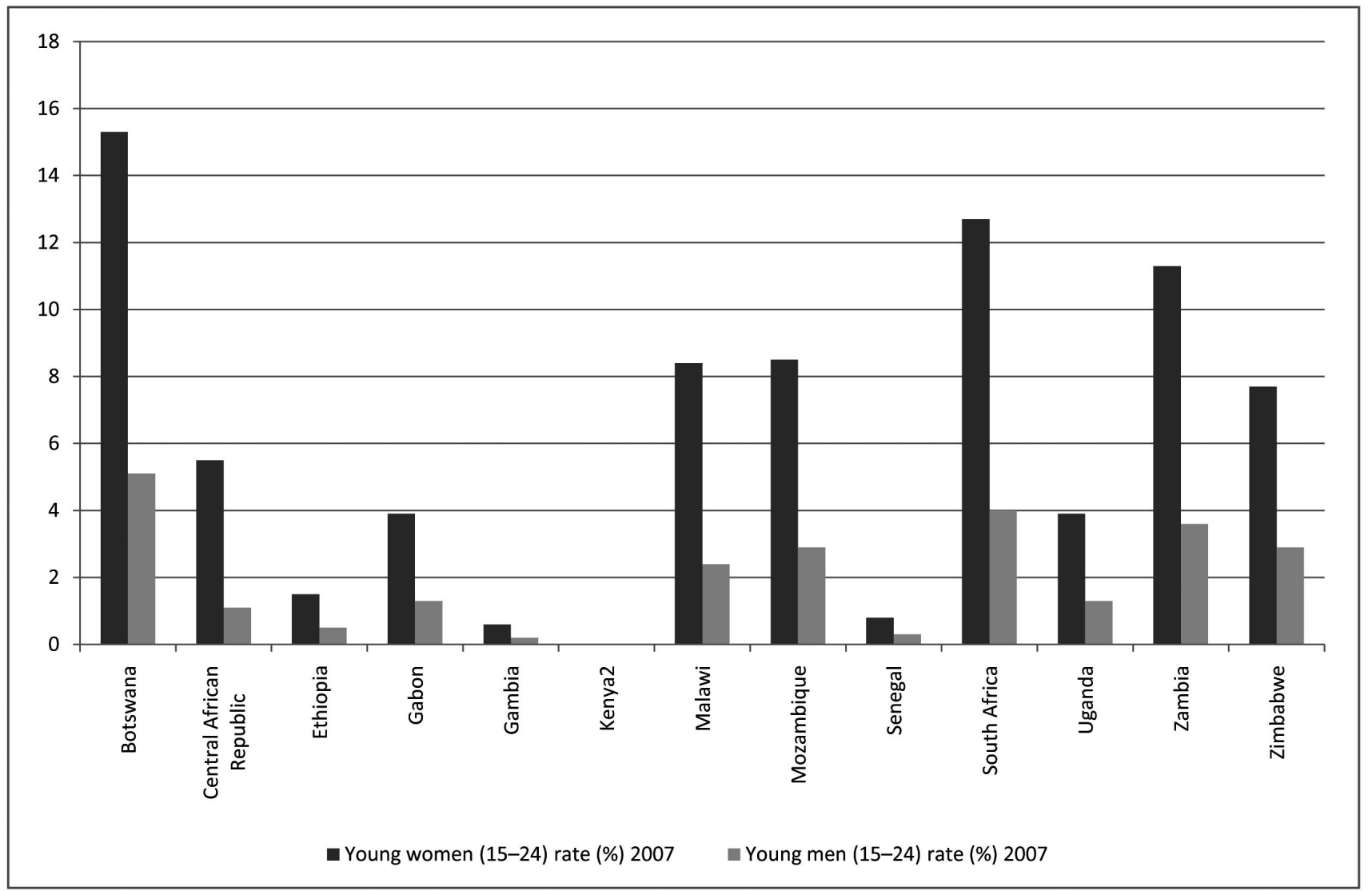

Source [6].

Fig. (2). HIV prevalence among young (15-24) women and men, 2007. 
Table 2. SSA Case Countries, HIV/AIDS Epidemiology

\begin{tabular}{|c|c|c|c|c|c|c|c|c|c|c|c|}
\hline & \multicolumn{4}{|c|}{ 1. Estimated Number of People Living with HIV } & \multicolumn{2}{|c|}{ 2. AIDS Deaths } & \multicolumn{5}{|c|}{ 3. Treatment } \\
\hline & 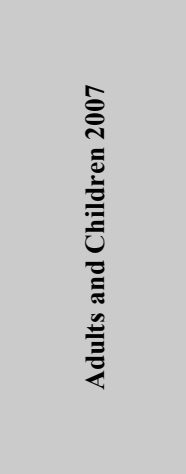 & 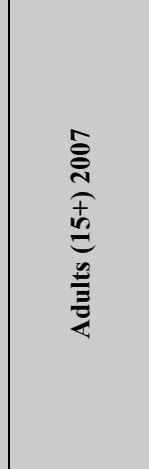 & \multirow[t]{2}{*}{ 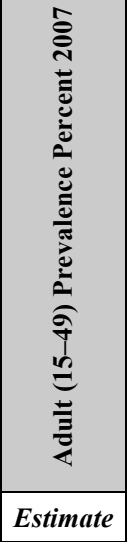 } & 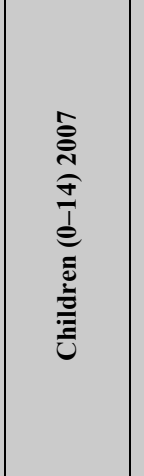 & \multirow[t]{2}{*}{ 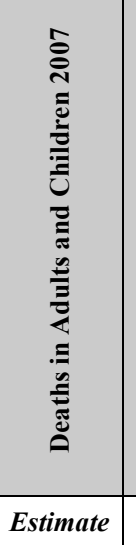 } & 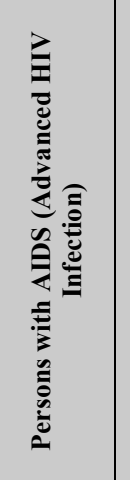 & 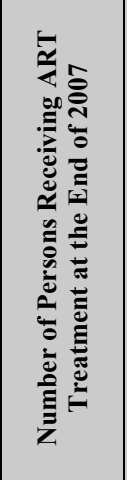 & \multicolumn{2}{|c|}{ 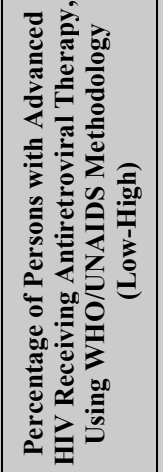 } & \multicolumn{2}{|r|}{ 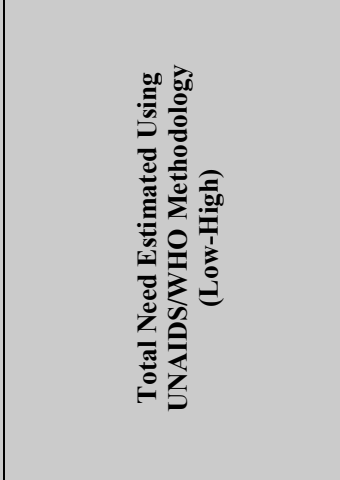 } \\
\hline Country & Estimate & Estimate & & Estimate 1 & & & Estimate & Esti & & & Estimate \\
\hline Botswana & 300000 & 280000 & 23.9 & 15000 & \begin{tabular}{l|l}
11000 & 2 \\
\end{tabular} & 237000 & 92932 & \multicolumn{2}{|c|}{$79[69->95]$} & \multicolumn{2}{|r|}{$120000[100000-130000]$} \\
\hline Central African Republic & 160000 & 140000 & 6.3 & 14000 & 11000 & 33600 & 9591 & \multicolumn{2}{|c|}{$21[18-27]$} & \multicolumn{2}{|r|}{$45000[36000-54000]$} \\
\hline Ethiopia & 980000 & 890000 & 2.1 & 92000 & $67000 \quad 2$ & 284200 & 90212 & \multicolumn{2}{|c|}{$29[25-36]$} & \multicolumn{2}{|r|}{$310000[250000-370000]$} \\
\hline Gabon & 49000 & 46000 & 5.9 & 2300 & 2300 & 20580 & 6373 & \multicolumn{2}{|c|}{$42[30-60]$} & \multicolumn{2}{|r|}{$15000[11000-21000]$} \\
\hline Gambia & 8200 & 7500 & 0.9 & $\ldots$ & $\ldots$ & 1476 & 431 & \multicolumn{2}{|c|}{$18[12-37]$} & \multicolumn{2}{|r|}{2300 [1200-3700] } \\
\hline Kenya $^{2}$ & $\ldots$ & $\ldots$ & $\ldots$ & $\ldots$ & 107500 & & 177000 & 38[ & $-48]$ & & {$[370000-570000]$} \\
\hline Malawi & 930000 & 840000 & 11.9 & 91000 & $68000 \quad 3$ & 325500 & 100649 & 35[ & $-42]$ & & 0000 [240000-340000] \\
\hline Mozambique & 1500000 & \begin{tabular}{l|l}
0 & 1400000 \\
\end{tabular} & 12.5 & 100000 & 81000 & 360000 & 89592 & 24[ & $-31]$ & & 70000 [290000-460000] \\
\hline Senegal & 67000 & 64000 & 1.0 & 3100 & 1800 & 37520 & 6699 & 56[ & $-70]$ & & $12000[9600-15000]$ \\
\hline South Africa & 5700000 & \begin{tabular}{l|l}
0 & 5400000 \\
\end{tabular} & 18.1 & 280000 & \begin{tabular}{l|l}
350000 & 15 \\
\end{tabular} & 1596000 & 458951 & 28[ & $-36]$ & 1700 & 00 [1300000-2100000] \\
\hline Uganda & 940000 & 810000 & 5.4 & 130000 & 77000 & 310200 & 115348 & 33[ & $-40]$ & & 50000 [290000-430000] \\
\hline Zambia & 1100000 & 980000 & 15.2 & 95000 & \begin{tabular}{l|l}
56000 & 5
\end{tabular} & 506000 & 151199 & 46[ & $-56]$ & & $30000[270000-380000]$ \\
\hline Zimbabwe & 1300000 & \begin{tabular}{l|l}
0 & 1200000 \\
\end{tabular} & 15.3 & 120000 & \begin{tabular}{l|l}
140000 & 2 \\
\end{tabular} & 234000 & 97692 & 18[ & $-23]$ & & 70000 [440000-690000] \\
\hline & 4. Expenditure & & & & & & & & & & \\
\hline & & Prevent & & & & & & Ire and & reatn & ment & \\
\hline Country & 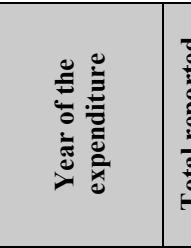 & 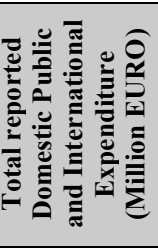 & 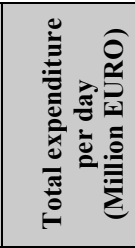 & 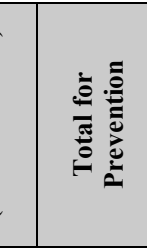 & 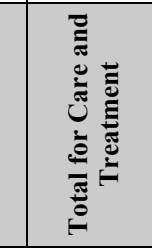 & 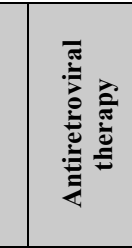 & 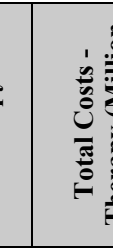 & 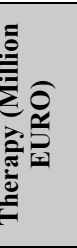 & 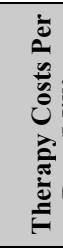 & 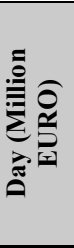 & 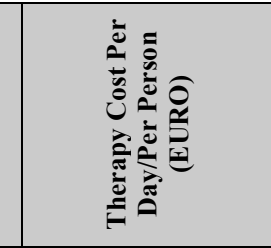 \\
\hline Botswana & 2007 & 155.57 & 0.426 & $\$ 15.995$ & $5 \quad \$ 140.364$ & $4 \quad \$ 44.482$ & & 5.33 & & .343 & 3.695 \\
\hline Central African Republic & 2006 & 10.83 & 0.030 & $\$ 2.032$ & $\$ 5.596$ & $\mathrm{NA} / \mathrm{NR}$ & 4. & 12 & & .011 & 1.178 \\
\hline Ethiopia & & & NR & & & & & NR & & - & 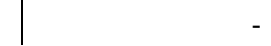 \\
\hline Gabon & 2007 & 6.57 & 0.018 & $\$ 3.489$ & $\$ 2.544$ & $\$ 1.828$ & & 96 & & .008 & 1.274 \\
\hline Gambia & 2007 & 11.48 & 0.031 & $\$ 16.023$ & $\$ 0.062$ & $\mathrm{NA} / \mathrm{NR}$ & 0. & .04 & & .000 & 0.268 \\
\hline Kenya $^{2}$ & & & & & & & & $\mathrm{NR}$ & & - & \\
\hline Malawi & 2005 & 45.42 & 0.124 & $\$ 5.758$ & $\$ 27.490$ & NA/NR & & 2.10 & & .061 & 0.602 \\
\hline Mozambique & 2006 & 70.39 & 0.193 & $\$ 31.555$ & $\$ 35.489$ & \begin{tabular}{l|l}
19.422 \\
\end{tabular} & 40 & .47 & & .111 & 1.238 \\
\hline Senegal & 2007 & 12.08 & 0.033 & NA/NR & NA/NR & $\mathrm{NA} / \mathrm{NR}$ & & .00 & & - & - \\
\hline South Africa & 2007 & 421.46 & 1.155 & NA/NR & NA/NR & NA/NR & & .00 & & - & 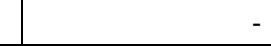 \\
\hline Uganda & 2005 & 162.75 & 0.446 & $\$ 37.841$ & $\$ 85.149$ & $\$ \$ 59.231$ & 116 & 6.08 & & .318 & 2.757 \\
\hline Zambia & 2006 & 139.98 & 0.384 & $\$ 47.062$ & \begin{tabular}{l|l}
2 & $\$ 89.306$
\end{tabular} & $5 \quad \$ 38.992$ & 94 & 1.56 & & .259 & 1.713 \\
\hline Zimbabwe & 2006 & 95.45 & 0.262 & NA/NR & NA/NR & $\mathrm{NA} / \mathrm{NR}$ & & .00 & & - & \\
\hline
\end{tabular}




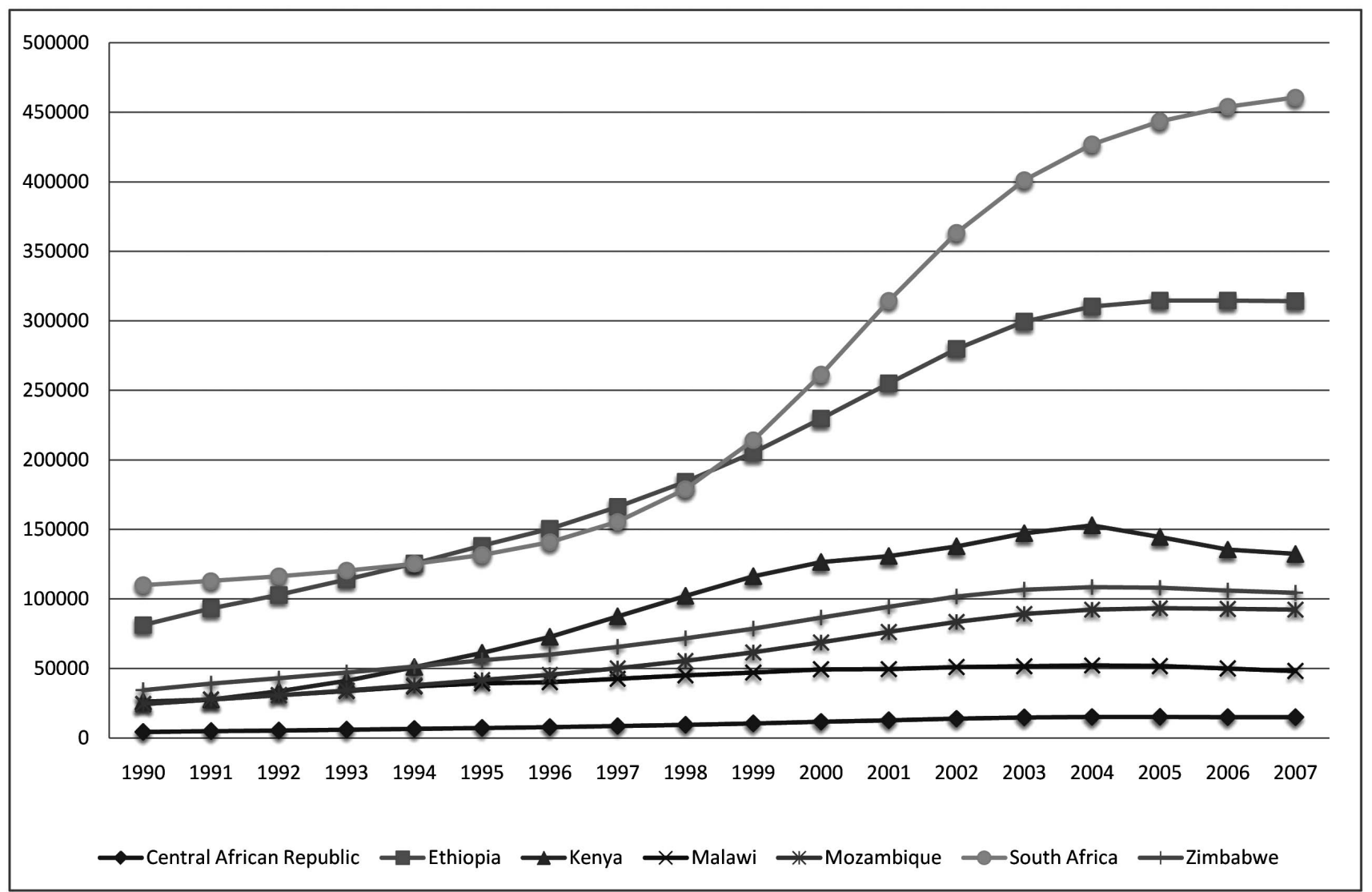

Source: [4].

Fig. (3). TB incidence in select SSA case countries, 1990-2007.

XDR TB is very sketchy. XDR TB has only been reported in four case countries, namely Botswana (2 cases), Kenya (1 case), Mozambique (2 cases) and South Africa (996 cases).

\section{DIAGNOSTICS}

\section{Method}

The researchers were unable to obtain information on the use of diagnostic tools and their cost in the case countries, apart from South Africa. In the South African case, information was obtained through interviews with experienced laboratory diagnostic service providers at SUN. The cost structure of diagnostic services in South African public institutions is (principally) determined by the annual tariffs set by the NHLS in its annual pricing catalogue. In the private sector, diagnostic services are provided by a large number of service providers who are free to set marketrelated charges; diagnostic costs thus vary between different entities. The government does not regulate these costs and there is no price ceiling or cap. However, the state does issue 'reference prices' which are then accessible to clients and which form a benchmark for private sector competitiveness. These price lists are issued annually by the Department of Health (DoH) through the National Health Reference Price List. The researcher utilised both the NHLS price list (2008/09) and DoH price list (2009).

The cost of TB and HIV diagnostic services were recalculated into Euro using the average Euro/Rand exchange rate for 2008. It should be noted that the costs for diagnostic services in public institutions are not automatically transferred onto patients. Most clinics/hospitals do not charge for these services because the majority of patients are non-fee paying, as determined by their income status (means based determination). Private institutions do not utilize the same range of tests in disease diagnosis. In screening patients for TB, for example, private institutions do not use skin tests. Similarly drug resistance tests are only conducted by institutions aligned to the NHLS and there are only a handful of research laboratories able to carry out these tests. Tygerberg, for example, is the only NHLS laboratory that currently offers routine genotypic HIV drug resistance testing.

\section{Outcome}

The main diagnostic tests for HIV/AIDS and TB and their indicative costs are presented in Table 4. HIV rapid and/or ELISA tests are routinely conducted to test for infection. If the first screening test has a positive (reactive) result, the sample is retested to confirm the result. CD4 counts (PLG method) are then undertaken to determine whether patients quality for ART (cut-off 200 cells/ $\mu 1$ ) and thereafter routinely every 6 months in parallel to monitor the treatment response of patients on ART, in parallel with HIV viral load tests (EasyQ method). (Beginning in 2010, the viral load method has been changed, the eligibility criteria for ART have been altered and the frequency of follow-up testing has been reduced). In the diagnosis of TB, skin tests are routinely used in the public sector (i.e. state run hospitals 
Table 3. TB Epidemiology

\begin{tabular}{|c|c|c|c|c|c|c|c|c|c|}
\hline & & $\begin{array}{l}\text { New } \\
\text { Pulmonary }\end{array}$ & & $\begin{array}{l}\text { New } \\
\text { Extra- }\end{array}$ & & \multicolumn{2}{|c|}{ MDR } & \multirow{2}{*}{$\begin{array}{l}\begin{array}{l}\text { Estimated } \\
\text { Incidence }\end{array} \\
\text { All Forms }\end{array}$} & \multirow[b]{2}{*}{ ss+ } \\
\hline & $\begin{array}{l}\text { New and } \\
\text { Relapse }\end{array}$ & ss + & ss-/unk. & Pulmonary & & & & & \\
\hline & Number & Number & Number & Number & $\begin{array}{l}\text { Total } \\
\text { New }\end{array}$ & $\begin{array}{l}\% \text { of New } \\
\text { Cases }\end{array}$ & New MDR & Number & Number \\
\hline Botswana & 7,622 & 3,002 & 3,092 & 1,305 & 7,399 & 1 & 63 & 13,761 & 5,251 \\
\hline Ethiopia & 128,844 & 38,040 & 43,500 & 45,269 & 126,809 & 2 & 2,050 & 314,267 & 135,311 \\
\hline Gabon & 3,766 & 1,462 & 1,678 & 409 & 3,549 & 1 & 48 & 5,408 & 2,208 \\
\hline Gambia & 1,916 & 1,238 & 541 & 91 & 1,870 & 0 & 9 & 4,415 & 1,936 \\
\hline Kenya & 106,438 & 38,360 & 49,869 & 18,032 & 106,261 & 2 & 2,036 & 132,357 & 53,226 \\
\hline South Africa & 315,315 & 135,604 & 105,631 & 45,738 & 286,973 & 2 & 5,208 & 460,600 & 173,710 \\
\hline Uganda & 40,909 & 21,303 & 13,713 & 4,460 & 39,476 & 1 & 211 & 101,785 & 41,865 \\
\hline Zambia & 46,320 & 13,378 & 21,189 & 10,015 & 44,582 & 2 & 801 & 60,337 & 22,956 \\
\hline \multirow[t]{3}{*}{ Zimbabwe } & 40,277 & 10,583 & 21,964 & 6,381 & 38,928 & 2 & 749 & 104,400 & 39,784 \\
\hline & $\begin{array}{l}\text { Estimated } \\
\text { Prevalence }\end{array}$ & & & $\begin{array}{c}\text { HIV } \\
\text { Prevalence }\end{array}$ & $\begin{array}{l}\text { TB } \\
\text { Mortality, } \\
2007\end{array}$ & & MDR, 2007 & $\begin{array}{l}\text { New } \\
\text { Smear- } \\
\text { Positive } \\
\text { Cases, } \\
\text { DOTS }\end{array}$ & \\
\hline & All Forms* & $\begin{array}{l}\text { All Forms } \\
\text { HIV+ }\end{array}$ & $\begin{array}{l}\text { HIV+ of } \\
\text { All Forms }\end{array}$ & $\begin{array}{c}\text { in } \\
\text { Incident }\end{array}$ & $\begin{array}{c}\text { All } \\
\text { Forms* }\end{array}$ & $\begin{array}{l}\text { All Forms } \\
\text { HIV+ }\end{array}$ & $\begin{array}{c}\text { Number } \\
\text { Among }\end{array}$ & $\begin{array}{c}\% \\
\text { Success }\end{array}$ & \\
\hline Kenya & 119,842 & 31,672 & 26 & 48 & 24,435 & 14,588 & 3,532 & 85 & \\
\hline Malawi & 42,447 & 16,396 & 39 & 68 & 14,167 & 11,293 & 1,555 & 78 & \\
\hline Mozambique & 107,752 & 21,838 & 20 & 47 & 27,200 & 17,480 & 3,394 & 83 & \\
\hline Senegal & 57,939 & 2,101 & 4 & 12.5 & 7,982 & 1,863 & 1,250 & 76 & \\
\hline South Africa & 335,911 & 167,799 & 50 & 73 & 111,924 & 93,702 & 15,914 & 74 & \\
\hline Uganda & 131,636 & 19,688 & 15 & 39 & 28,686 & 16,110 & 805 & 70 & \\
\hline Zambia & 46,115 & 20,977 & 45 & 70 & 13,661 & 10,624 & 1,249 & 85 & \\
\hline Zimbabwe & 95,298 & 35,980 & 38 & 69 & 35,343 & 28,409 & 2,863 & 60 & \\
\hline
\end{tabular}

ss + indicates sputum smear-positive; ss-, sputum smear-negative; unk., sputum smear result unknown; re-treat., re-treatment; pulm. lab. confirmed, pulmonary case confirmed by positive smear or culture.

Source: [4] and authors calculations.

and clinics), but rarely in the private sector. Chest X-rays are carried out on suspected patients and those testing positive to the skin test. Microscopy tests (Ziehl-Neelsen) are then routinely carried out to confirm the result. The cost indicated in Table 4 includes the sputum sample collection and fluid preparation costs. PCR is used in the case of children. In patients with active TB genotypic resistance tests (Hain) are routinely used when drug resistance is suspected.

\section{INTER-CULTURAL SENSITIVITIES}

\section{Method}

The researchers examined WHO/UNAIDS/UNICEF country reports on the management of TB and HIV/AIDS treatment to identify key challenges and issues of intercultural sensitivity that could affect the conduct of 
Table 4. HIV and TB Diagnostic Costs

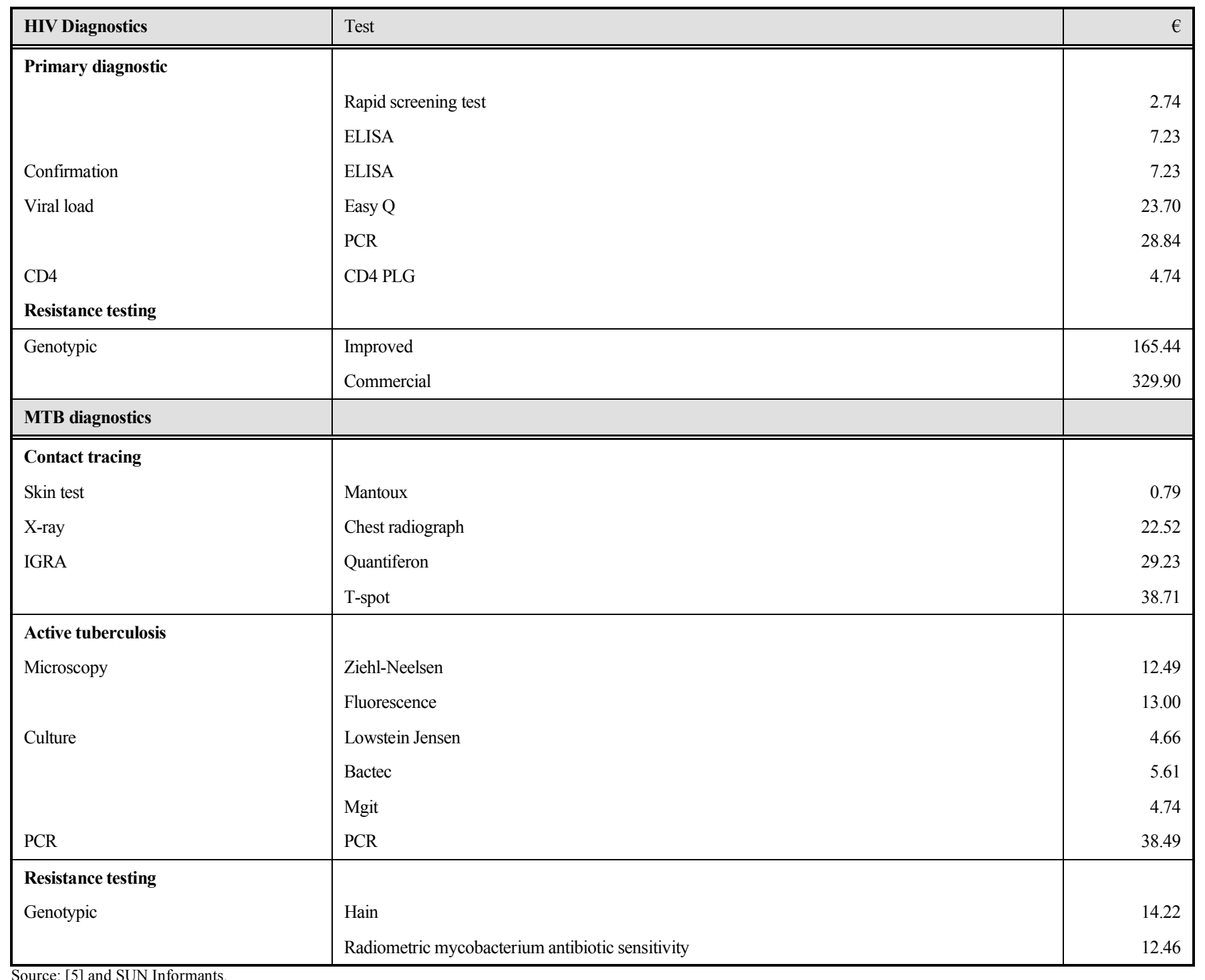

biomedical research. The researchers also consulted reports on the framework conditions for medical research in particular countries, where these could be identified in open access data. The researchers drew extensively on the country reports produced by Research Africa (http://research africa.rti.org) and the infectious diseases reports issued by the United States Agency for International Development (USAID) (http://www.usaid.gov/our_work/global_health). Additionally, we examined the websites of leading research institutions, programmes and information portals, including:

- Armauer Hansen Research Institute (http://www.tele com.net.et/ ahri/)

- Botswana HSPH AIDS Initiative (http://www.hsph. harvard.edu)

- $\quad$ FIND (http://findiagnostics.org),

- Kenya Medical Research Institute (KEMRI) (http:// www.kemri.org)

- Medical Research Council Laboratories (Gambia) (http://www.mrc.gm),
- $\quad$ Malawi-Liverpool-Wellcome Trust Clinical Research Programme (http://www.mlw.medcol.mw),

- $\quad$ South African Medical Research Council (http://ww w.mrc.ac.za),

- South African Health Info (http://www.sahealthinfo. org)

- University of Zimbabwe, College of Health Sciences (http://www.uz-ucsf.co.zw).

- Uganda Virus Research Institute (http://www.iavi. or.ug)

- Joint Clinical Research Centre (http://www.jcrc. co.ug).

Country-specific procedures and protocols for ethical approval of medical research involving human subjects were identified through web-searching. We thus could identify the institutions responsible for ethical requirements in each country, apart from the Central African Republic where it seems that no institution has been mandated this role. 
In order to benchmark the state of the medical industry in the case countries, our research drew on the WHO World Health Statistics 2008 [7] report. This data enables a comparison between the 13 case countries in terms of their health workforce and expenditure (public and private) outlay, see Table 5.

\section{Outcome}

There are a number of common challenges to conducting biomedical research in the case countries. The greatest challenge relates to the deficiency in skills, including clinical, bio-technological and bio-engineering expertise. Most African countries do not have adequate skills and managerial expertise to run complex research programmes and are therefore reliant on expatriate scientists. Botswana, as one case, started her first medical school only in August 2009. The role of expatriates is reinforced through the provision of grants. All research institutions in SSA, including those in South Africa, depend heavily on funding from northern countries and global institutions. The dependence on foreign grants is manifest in the control that northern institutions, especially European and American institutions, have over most HIV/AIDS and TB research programmes. The role of African institutions in these programmes is often no more than an operational base for the collection and logistical handling of human blood, sputum, tissue and other samples. The nature of this dominance varies: at best there is evidence of institutional capacity building and skills transfer, at worst there is evidence of neo-colonial influence to create access to research populations and exclude competing institutions.

The constraints to doing research are greatest in the LDCs: Central African Republic, Ethiopia, Gambia, Malawi, Mozambique, Uganda and Zambia. Uganda, however, has partially overcome some of these challenges through investing in medical and research institutions to combat HIV/AIDS and through fostering strong collaborations with UK and USA institutions. Conducting field research in the LDCs is comparatively costly: virtually all research inputs (such as equipment or antigens) have to be imported; transport and communications systems are poorly developed, necessitating higher logistical costs and often time delays; utilities and services (including power, water and waste disposal) are unreliable and require on-site back-up facilities; and government procedures (including ethical approval, immigration permits, export and import permits) are usually highly bureaucratic and the process is tedious. The ethically and socially acceptable research study procedures, including the collection of specific sample types and allowable blood volumes that can be collected from research study participants vary substantially across countries.

Among the middle income group of case countries there are also success stories, notably in Kenya and South Africa. Both countries have developed a strong biomedical sector through collaboration and private sector initiatives in drug trials and manufacture. The governments in both countries have invested more heavily in skills development, producing a sizable labour pool of clinicians, skilled technicians, research nurses and engineers that largely meets domestic demand. Yet their labour markets are rigid and it is difficult to recruit high calibre foreign skills to enhance project expertise. Specific government support to grow biomedical research capability and build research institutions is generally weak or absent in most SSA countries. South African institutions, in exception, are able to obtain state grants from the National Research Foundation (NRF) and Medical Research Council (MRC). However, the country's research institutions have been given little support (political or financial) to extend their research activities into Africa and build institutional collaborations with African institutions. South Africa plays little role in seeking to combat HIV/AIDS and TB outside its borders, even among its neighbours. This is both a failure in foreign policy and equally a reflection of the under-resourced status of South African institutions.

\section{ANALYSIS OF BIOMEDICAL RESEARCH FUNDING}

\section{Method}

African biomedical research institutions rely heavily (exclusively in most of the case countries) on foreign funding. In order to identify the source and value of these grants, the researchers sought to examine the funding awarded to institutions in the case countries by the leading donors in the respective diseases. These leading donors were identified from recent studies. In TB research, the research drew upon the findings of the Treatment Action Group (TAG) study Tuberculosis Research and Development: A Critical Analysis [8], while for HIV/AID we consulted the report published by the HIV Vaccines and Microbicides Resource Tracking Working Group Sustaining the HIV Prevention Research Agenda: Funding for Research and Development of HIV Vaccines, Microbicides and other New Prevention Options [9]. These studies enabled us to determine the leading ten donors/institutions providing grants to African institutions in each field respectively.

Biomedical research funding is dominated by United States of America (USA) funders that include public institutions and private (not-for-profit) foundations. The largest funders are the institutions of the Department of Health and Human Services' (DHHS) operating divisions, which include the National Institutes for Health (NIH) and Centre for Disease Control and Prevention (CDC). Among private donors, the Bill and Melinda Gates Foundation (BMGF) is the largest donor, funding research institutions directly and providing funds indirectly through intermediate institutions, such as AERAS and global bodies such as WHO. In TB research, the DHHS institutes and BMGF contribute approximately $62 \%$ of the total financial pool awarded by the top twenty donors; their combined funding potentially equals more than half the total global funding awarded for biomedical research in this disease. ${ }^{2}$ Apart from the BMGF, other major USA donors (of primary funds) for research in HIV/AIDS are the American Foundation for AIDS Research (amFAR), Ford Foundation and the Elizabeth Glaser Paediatric AIDS Foundation (EGPAF).

\footnotetext{
${ }^{2}$ The DHHS Institutes and BMGF awards account for $59 \%$ of the total sum awarded by the top 40 donors of research in TB.
} 
Table 5. Health Workforce and Expenditure in the SSA Case Countries

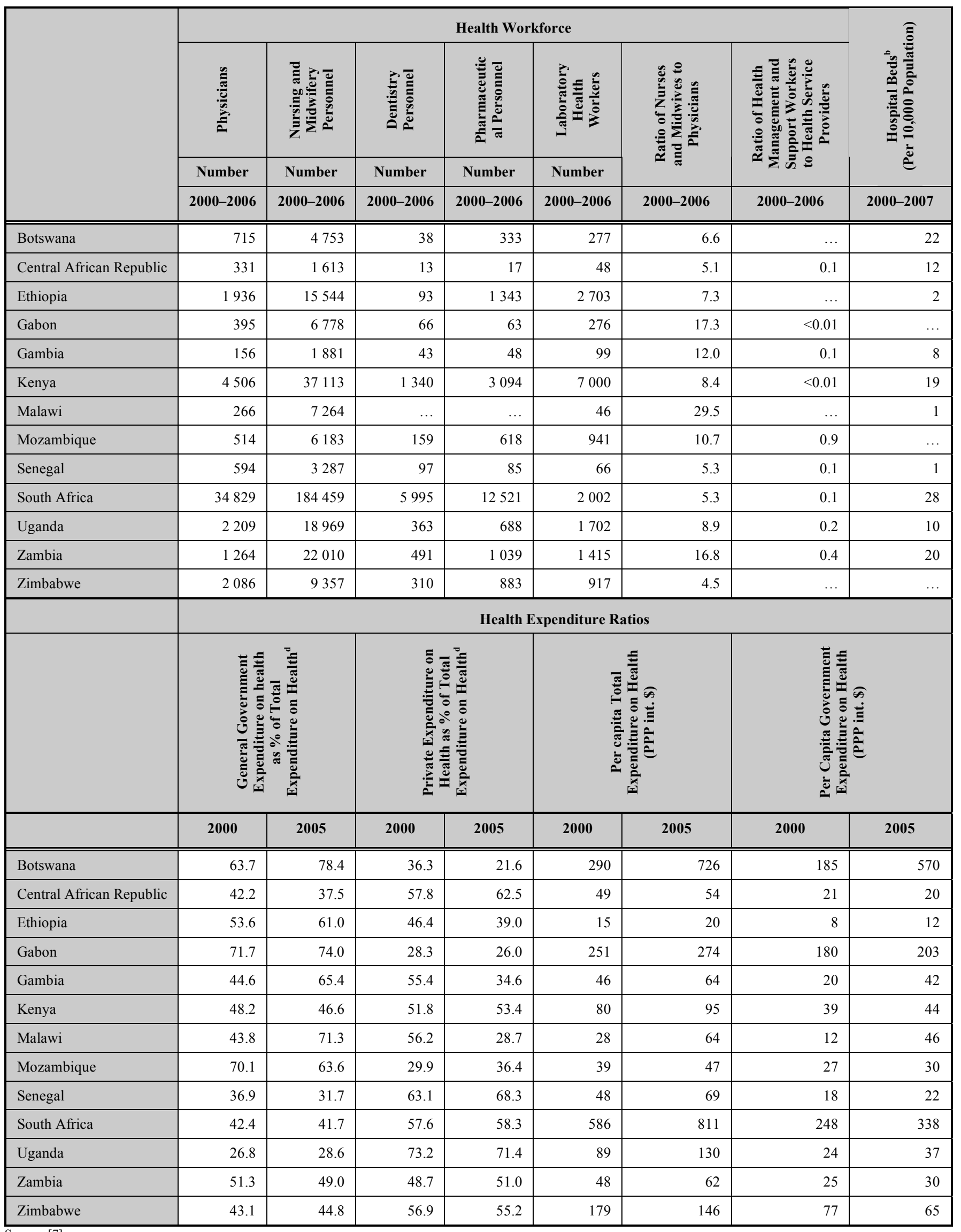


Outside the USA, other top ten donors are the Medical Research Council (UK), the Wellcome Trust (UK), and the European and Developing Countries Clinical Trials Programme (EDCTP) (European Union). Also significant, though tending to restrict their funds to Northern institutions, are the Canadian Institute of Health Research (CIHR), Netherlands Ministry of Foreign Affairs (MoFA), Agence Nationale de Recherches sur le Sida et les Hepatites Virales (ANRS, France) and the Max Planck Institute (Germany).

Commercial pharmaceutical companies are known to invest heavily in drug research and vaccine trials, though details of the grants they provide and their investments are not publicly accessible. The TAG study on TB funding, for example, reported that of those pharmaceutical companies willing to disclose the extent of their funding, Otsuka, AstraZeneca, Inserm, and Novartis International fall within the top 20 group of funders. In case of HIV vaccine research and development (R\&D), commercial investment in 2007 was estimated to be $€ 54$ million. It is thought that $90 \%$ of these funds come from large companies; the largest funders in 2007 were considered to be Merck \& Co. (over US\$10 million), GlaxoSmithKline, Novartis, Sanofi Pasteur (between US\$5-10 million), and GeoVax and Wyeth-Ayerst Lederle (between US\$1-5 million) (HIV VMRTWG, 2008:16).

Focusing on the top ten funders/donors, the researchers sought to identify open-source information detailing the allocation of awards. The researchers also examined the grants awarded by the National Research Foundation (NRF), an important (financially and in institutional terms) funder of biomedical research, especially TB, in South Africa. In 2005, the year for which TAG data is available, the NRF invested $€ 1.314$ million in TB research, an amount that would have placed it in $28^{\text {th }}$ position in the ranking table.

Our focus was exclusively on grants awarded directly to indigenous institutions in the 13 case countries to pursue TB and or HIV/AIDS biomedical research. The criteria excluded awards to non-country partner institutions (including European and American institutions), even though these institutions may utilise the award principally to conduct research in the case country through a resident programme. The criteria also excluded research into behavioural, epidemiological, economic or socio-cultural aspects of the disease burden. However, the review did included funding for biomedical research capacity building, even though some of the large grants that fell within this category - especially those given to the University of KwaZulu Natal (UKZN) and University of Witwatersrand (WITS) - include aspects of behavioural and epidemiological studies.

The researchers were able to access open source information on grant awards from the following funders: NIH, CDC, BMGF, Wellcome Trust, MRC (UK), EDCTP, CIHR and NRF. Although these institutions all adhere to principles of transparency in funding (albeit to different degrees), the information is not easily accessible. It proved difficult, often impossible to differentiate between grants awarded to Northern institutions and the portion of the grant given to the partner institution in the case country. Furthermore, several of the institutions obfuscate grant transparency through failing to regularly and systematically update the information on their website. In many cases, the public can only learn the financial details on awards after projects have been completed; the NRF is notably weak in this respect.

The researchers were able to access up-to-date information on awards made by DHHS institutions through three on-line tools, namely:

- Computer Retrieval of Information on Scientific Projects (CRISP) (http://crisp.cit.nih.gov/crisp),

- $\quad$ NIH Research Online Reporting Tool (RePORT) (http://report.nih.gov).

- Tracking Accountability in Government Grants System (TAGGS) data base (http://taggs.hhs.gov/).

The use of all three tools proved necessary to triangulate information and fill in gaps. The CRISP system provides abstracts of funded projects, but it does not indicate the amount awarded to the grantee. The RePORT tool enabled the researchers to identify NIH grants awarded to specific projects and institutions in the case countries. The TAGGS tool enabled the researchers to identify awards given to institutions to conduct basic research and build capacity. It includes information on CDC grants. The TAGGS tool revealed the comparatively large number of grants awarded by USA institutions to organisations in the case countries for treatment and prevention actions. Although this topic falls outside the terms of reference, the impact of these awards on building research capacity should not be discounted, especially in those countries that have been heavily funded (Uganda, Kenya, Zimbabwe and South Africa).

Using the three tools, crude information was obtained through searches using key words: country (+ institution) + TB and country (+ institution) + HIV/AIDS. The researchers double-checked the outcome through carrying out a secondary search using the name of recognised African research institutions and (where geographic information was available) the name of major towns in which African institutions are located. The crude data was then transferred into an Excel spreadsheet and arranged under basic headings: fiscal year, institution (beneficiary), grant number, principal investigator, award amount and grant making institution/organisation. Where the researchers was able to obtain detailed information about the awarded project (the project 'abstract'), this information was compiled into a separate database. The researchers converted the awarded amount into Euro on the basis of the annual average exchange rate of the year in which the grant was awarded.

A similar methodological approach was utilised to identify, collect, and organise the data from other North American, European and South African funding bodies. It is important to note that the analysis considered the value of the grant as specified on the website and not the amount that was actually disbursed. In obtaining information from each institution, the researchers confronted a number of specific challenges as detailed below:

Bill and Melinda Gates Foundation (USA): The BMGF, through its website, provides general information about all awards, including its Global Health Awards, Grand Challenge (GC) Awards, Collaboration for AIDS Vaccine Discovery (CAVD) Awards, Exploratory Awards, and other awards. BMGF does not provide details of the amount of 
funds actually awarded to the collaborating institutions. It is also not possible to determine what portion of the funds awarded through the Global Health mechanism actually gets spent in Africa or given to African institutions. In order to include the BMGF GC and CAVD awards in our case country data base, the researchers apportioned $10 \%$ of the total consortia award to each African collaborating institution; the figure is no more than an educated guess and the allocation may equate to a considerable underestimation in some cases.

Wellcome Trust (UK): The Trust releases, annually, a database of the awards it has granted. The information was accessible from its website.. The researchers were only able to access information for the period 2005-2007; at the time of writing, data for 2008 had yet to be released. While the Trust provides significant funds for biomedical research on both diseases in Africa, the bulk of these funds (apart from the South African case) are channelled through UK institutions to maintain country programmes, such as the London School of Hygiene and Tropical Medicine's (LHSTM) Karonga Prevention Study (KPS) or the MalawiLiverpool Wellcome Trust Clinical Research Programme. The researchers excluded grants awarded to programmes of this nature as the primary beneficiary was deemed to be the principal applicant (i.e. British institution).

Medical Research Council (UK): The UK MRC is the major donor to the MRC Laboratories in the Gambia and also supports a substantial field programme in Uganda. The respective country institutions play an important role in TB and HIV/AIDS research. The researchers were unable to identify, despite searching the MRC's website and consulting annual reports, the level of funding awarded to either the subsidiary institution or their specific research programmes. ${ }^{3}$

European and Development Country Trials Programme (EDCTP) (EU): The EDCTP provides access to information on (most) grants awarded via its website. The database, however, is not always complete (in several cases the actual amount awarded is not stated), whilst it was often not possible to disaggregate the total award among different consortia partners. The research identified data for 20052008. Anecdotal evidence from US informants would indicate that the EDCTP awards database may not include all grants to research endeavours in the case countries.

Canadian Institutes of Health Research (Canada): All CIHR awards are accessible via its website. Our search discovered that the CIHR provide no funds for biomedical research on either TB or HIV/AIDS to institutions in our case countries.

National Research Foundation (NRF) (South Africa): Awards made by the NRF can be identified through the Nexus Database System (http://stardata.nrf.ac.za); this system is partially open to public access. Through using key word searches, the researchers were able to identify grants awarded for HIV/AIDS and TB biomedical research to South African institutions. The data base currently includes all

\footnotetext{
3 The MRC's report 'Improving health, improving lives: MRC-funded research in Africa' is noticeably silent on its actual financial contribution to African institutions and research programmes.
}

projects funded up to 2006. The significance of the NRF contribution to biomedical research in the two diseases in the research timeframe thus could not be fully assessed. For the years 2004-2006, the NRF awarded approximately R16.7 million ( $€ 1.9$ million) for TB basic research, whereas it awarded a mere R1.7 million $(€ 200,000)$ to HIV/AIDS research.

\section{Other Funding Agents}

Two important South African funding agencies are the Medical Research Council (SA MRC) and the Poliomyelitis Research Foundation (PRF). The SA MRC can be partially considered as an 'agent' of larger funding organisations (including DHHS and BMGF) who redistribute funds to sub-grantees in local institutions. Neither the SA MRC nor PRF provide accessible and transparent information on their awards.

The researchers sought to identify sub-awards provided by the major global health initiatives that support TB and HIV/AIDS research in the case counties. Those bodies we examined were: Aeras Global TB Vaccine Foundation (AERAS), the Global Alliance for TB Drug Development (TB Alliance), the Foundation for Innovative New Diagnostics (FIND), and the International AIDS Vaccine Institute (IAVI). None of these bodies provide details of their investment and awards in partner countries.

\section{OUTCOME}

Our investigation found that in the 4 year period from 1 January 2005 to 31 December 2008 an amount of $\mathbf{€ 1 6 3 . 8 3 2}$ million was awarded to African institutions in the 13 case countries. This figure equates to an annual investment of roughly $€ 40$ million towards 'independent' African led biomedical research on HIV/AIDS and TB. An amount of $€ 6.539$ million awarded to research in Malawi (and Ethiopia, in one instance) was regarded as ineligible as the awards were considered to be given primarily to the leading European institution. The total eligible awards were thus €157.294 million.

The outcome of our research on funding permits four conclusions.

I. The allocation of biomedical research grants to African institutions is heavily skewed towards HIV/AIDS. All awards considered, $80 \%$ of the total value awarded was allocated to research in HIV/AIDS, whereas basic research on TB received only $8.4 \%$ and co-infection research $11.6 \%$ of the total sum identified. HIV/AIDS research also attracted a greater number of awards from large donors (particularly the DHHS, BMGF and Wellcome Trust).

II. The distribution in grants between the 13 case countries is highly unequal with South African institutions receiving $87 \%$ of the value of awards for HIV/AIDS research, $59 \%$ for $\mathrm{TB}$, and $89 \%$ for co-infection research. Six of the 13 countries (CAR, Ethiopia, Gabon, Gambia, Mozambique, and Zimbabwe) obtained no funding from the identified funders for HIV/AIDS research. Similarly, 8 countries (Botswana, CAR, Gabon, Kenya, Mozambique, Senegal, Zambia and Zimbabwe) obtained no award from these funders for TB research. 
III. The allocation of awards is biased towards large, well established, institutions that (practically) monopolize funding. In the field of HIV/AIDS research, the study identified 25 institutions that received grants, though only 11 received grants larger than $€ 1$ million. In the field of TB research, of the 16 institutions funded, only 7 institutions received grants exceeding $€ 1$ million. The EUCO-Net study proposed that the researchers identify the top 20 African institutions recipient of funding in both fields under consideration. Our research suggests that this would be misleading as there are approximately 15 African institutions that receive the bulk of HIV/AIDS funding and about 5 that receive the bulk of TB funding. The results of our analysis are presented in Figs. (4-6), corresponding to the three fields of investigation. In funding towards HIV/AIDS research, four institutions - UKZN, WITS, SA MRC and University of Cape Town (UCT) received $86 \%$ of the funds given to the 13 institutions receiving grants in excess of $€ 1$ million. UKZN heads the list, largely due to the extensive funding for the Africa Centre for Health and Population Studies (ACHPS) and the Centre for the AIDS Programme of Research in South Africa (CAPRISA). The amount of the funds award to UKZN affiliated institutions certainly overstates its role as a biomedical research institution as a significant portion of these funds are earmarked for non-biomedical research and capacity building. A similar comment can be made in respect of the funding status of WITS and its allied biomedical corporate arm (The Wits Health Consortium).

The position of several institutions in the top flight ( $>€ 1$ million) is owed to single grants, including our estimates of the BMGF allocations. In the field of TB research, only UCT and SUN have proved to be able to secure a succession of grants from the DHHS institutions. The potential capacity of the other leading African institutions in the field of TB biomedical research to acquire new grants is thus possibly overstated.

IV. The results of our investigation suggest that interventions that twin biomedical research with epidemiological, behavioural, and socio-economic studies (and moreover are able to link with preventative actions) are seemingly able to attract large (in value terms) grants from Northern funders. Pure biomedical research, in contrast, appears to be less heavily funded. There is also very little funding for building institutional capacity to carry out basic scientific research. Funding which does support capacity building is seemingly tied to specific programmatic interventions or projects. The findings of our analysis show that there are few stand alone grants to African institutions for enhancing skills to run research laboratories/field programmes and carry out basic investigative research. In this sense most of the case country institutions, apart from the top five in either field (and coinfection research), are evidently not seen by global funders as long term partners but rather as agencies for sample collection. For these institutions, grants are often once-off while an award in itself does not indicate the potential of the institution to receive further funding.

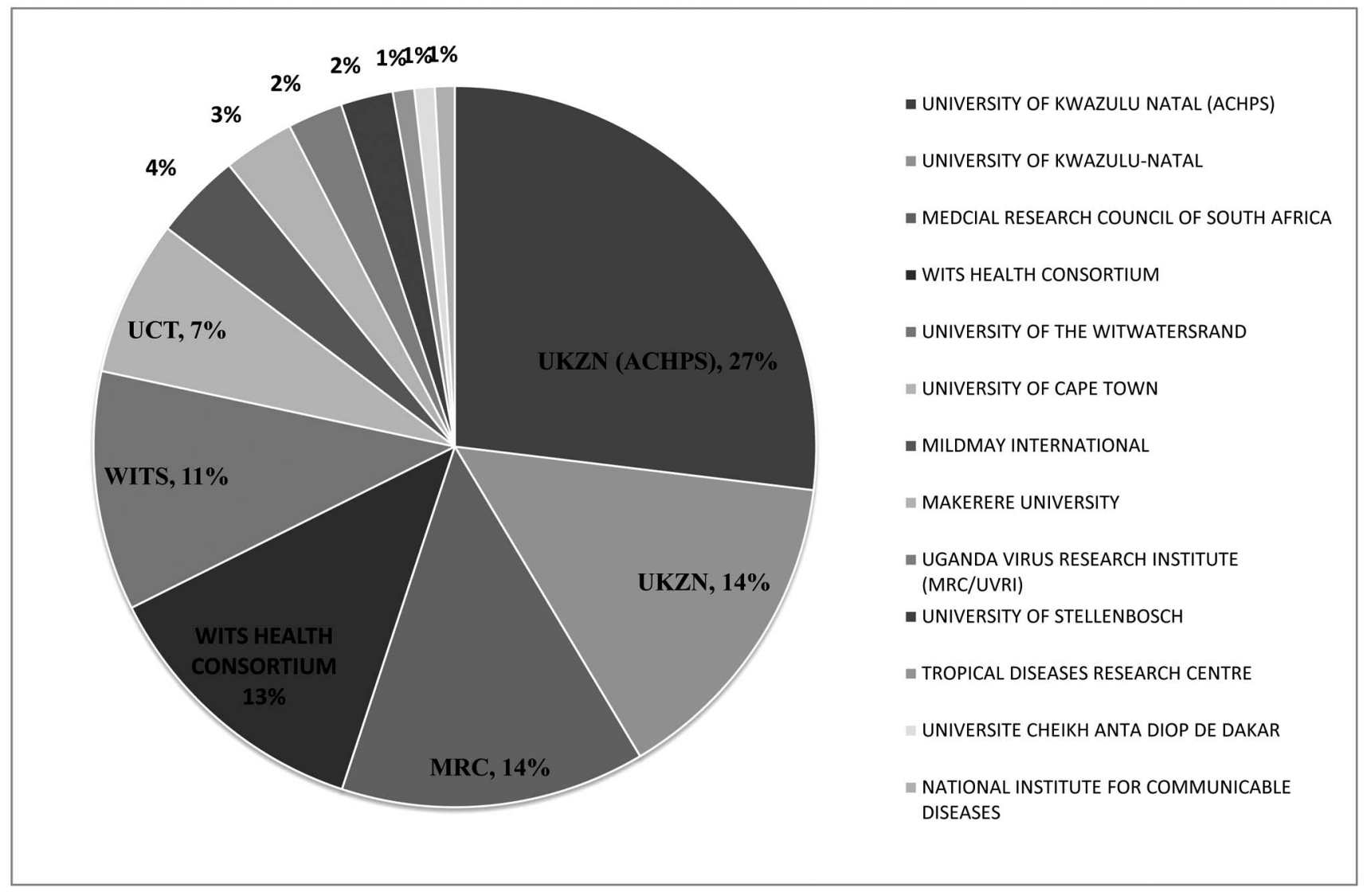

Fig. (4). Distribution of HIV/AIDS grants, showing institutions awarded $>€ 1$ million, 2005-2008. 


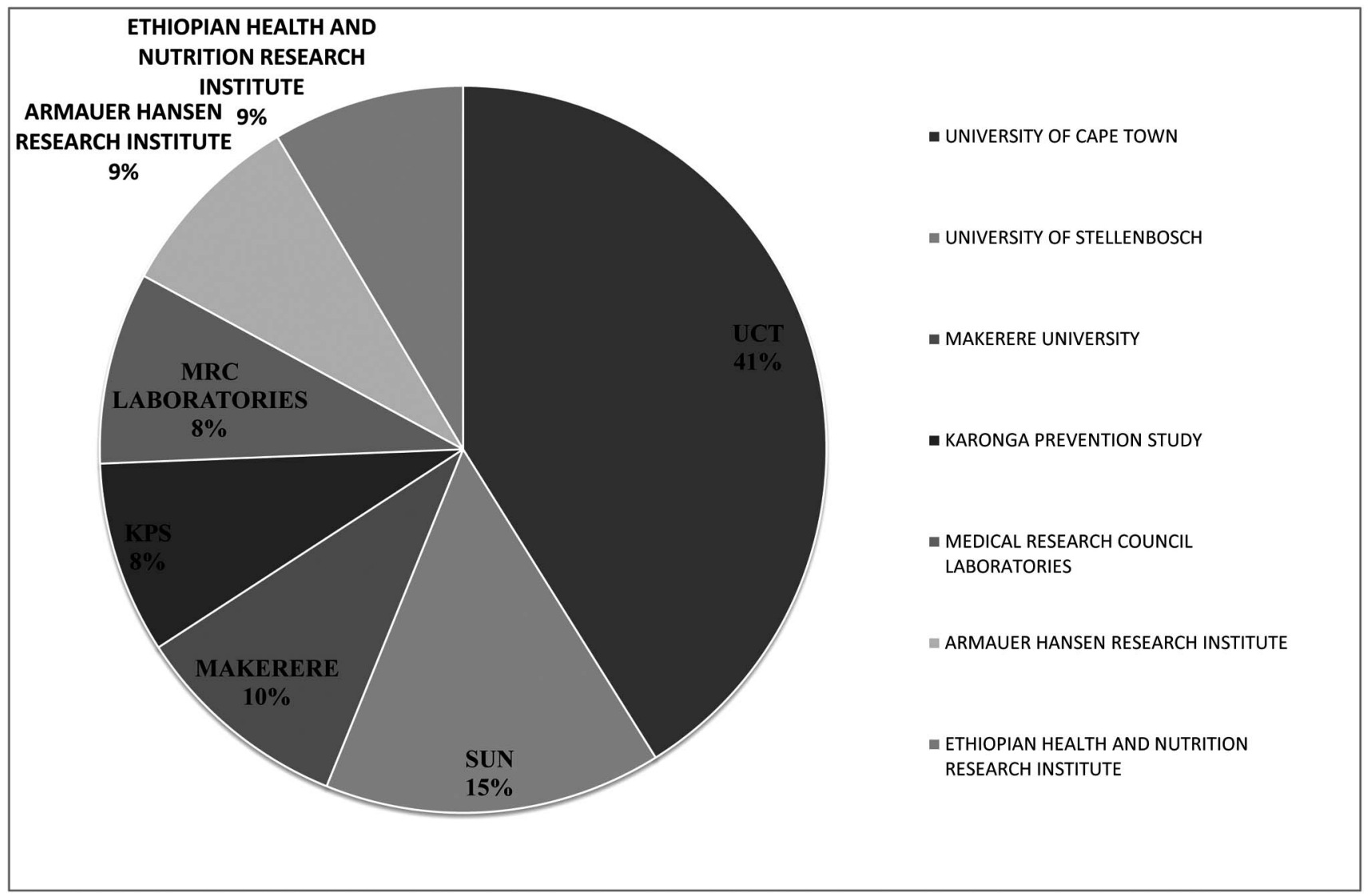

Fig. (5). Distribution of MTB grants, showing institutions awarded $>€ 1$ million, 2005-2008.

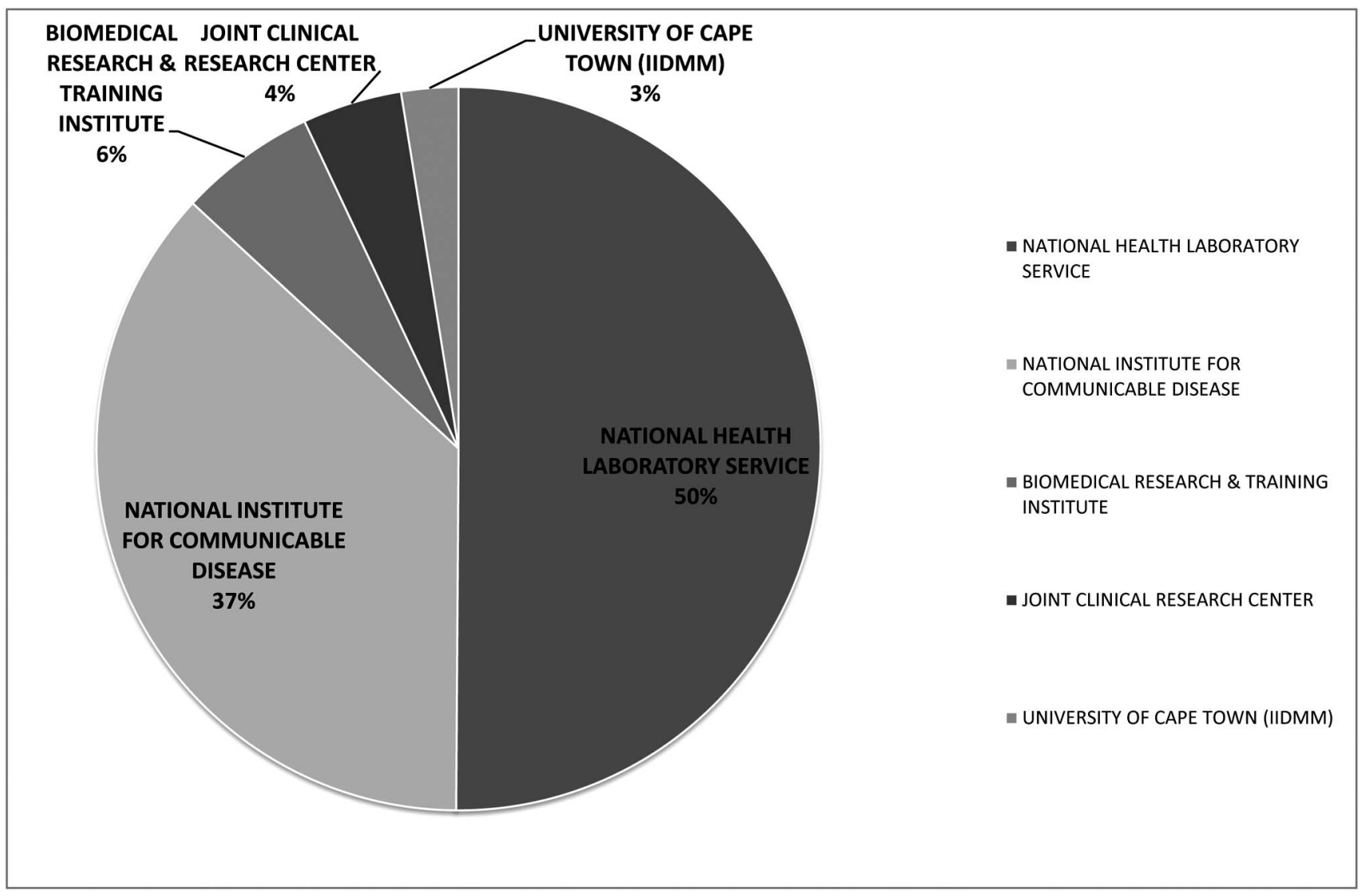

Fig. (6). Distribution of HIV/AIDS and MTB co-infection grants, showing institutions awarded $>€ 1$ million, 2005-2008. 
Table 6. HIV/AID Clinical Trial Stakeholders, 2005-2008

\begin{tabular}{|c|c|c|c|}
\hline Country & Universities (Lead) & Pharmaceuticals & Funders \\
\hline Botswana & $\begin{array}{l}\text { Harvard School of Public Health } \\
\text { McGill University Health Centre } \\
\text { Florida International } \\
\text { University of Washington } \\
\text { University of California, Los Angeles }\end{array}$ & $\begin{array}{l}\text { Gilead Sciences } \\
\text { Bristol-Meyers Squib } \\
\text { Boehringer Ingelheim }\end{array}$ & $\begin{array}{l}\text { BMGF } \\
\text { CDC } \\
\text { DHHS (NIAID) } \\
\text { CONRAD }\end{array}$ \\
\hline Ethiopia & John Hopkins University & & DHHS (NIAID) \\
\hline Gambia & & & DHHS (NIAID) \\
\hline Kenya & University of Washington & & $\begin{array}{l}\text { BMGF } \\
\text { CDC } \\
\text { DHHS (NIAID, NICHD) } \\
\text { IAVI } \\
\text { US Dept. of Defense } \\
\text { Washington Global Health Alliance }\end{array}$ \\
\hline Malawi & $\begin{array}{l}\text { University of North Carolina, Chapel Hill } \\
\text { Johns Hopkins Bloomberg School of Public Health } \\
\text { University of California, San Francisco }\end{array}$ & & $\begin{array}{l}\text { CDC } \\
\text { DHHS (NIAID, NICHD) } \\
\text { Family Health International }\end{array}$ \\
\hline Senegal & $\begin{array}{l}\text { Institut de Médecine et d'Epidémiologie } \\
\text { Appliuée - Fondation Internationale Léon MBA }\end{array}$ & Gilead Sciences & $\begin{array}{l}\text { French National Agency for Research } \\
\text { on AIDS and Viral Hepatitis }\end{array}$ \\
\hline South Africa & $\begin{array}{l}\text { University of Washington } \\
\text { University of California, Los Angeles } \\
\text { University of California, San Francisco } \\
\text { Columbia University } \\
\text { University of Missouri } \\
\text { University of Rochester } \\
\text { Université Bordeau } \\
\text { London School of Hygiene and } \\
\text { Tropical Medicine (LSHTM) } \\
\text { Columbia University } \\
\text { University of South Florida } \\
\text { University of Maryland } \\
\text { University of Miami } \\
\text { University of California, San Diego } \\
\text { Dartmouth-Hitchcock Medical Centre }\end{array}$ & $\begin{array}{l}\text { Boehringer Ingelheim } \\
\text { GlaxoSmithKline } \\
\text { Tibotec } \\
\text { Schering-Plough } \\
\text { Indevus } \\
\text { Bristol-Myers Squib } \\
\text { Gilead Sciences } \\
\text { Cipla Medpro }\end{array}$ & $\begin{array}{l}\text { HIV Vaccine Trials Network } \\
\text { BMGF } \\
\text { DHHS (NIAID, NIDA, NIMH, NIAAA, } \\
\text { NICHD, NCCAM) } \\
\text { CDC } \\
\text { Family Health International } \\
\text { International Partnership for Microbicides, Inc. } \\
\text { EDCTP } \\
\text { CONRAD } \\
\text { USAID } \\
\text { MRC } \\
\text { DfID } \\
\text { Doris Duke Charitable Foundation } \\
\text { Ibis Reproductive Health } \\
\text { SA MRC } \\
\text { NRF } \\
\text { Aids Malignancy Consortium }\end{array}$ \\
\hline
\end{tabular}




\begin{tabular}{|c|c|c|c|}
\hline Country & Universities (Lead) & Pharmaceuticals & Funders \\
\hline & & & US Dept of Defense \\
\hline Uganda & $\begin{array}{l}\text { University of Washington } \\
\text { University of Wisconsin } \\
\text { University of California, San Francisco } \\
\text { University of Oxford } \\
\text { University of North Carolina } \\
\text { LSHTM }\end{array}$ & $\begin{array}{l}\text { Indevus } \\
\text { Gilead Sciences } \\
\text { Abbott } \\
\text { Merck } \\
\text { Tibotec }\end{array}$ & $\begin{array}{l}\text { BMGF } \\
\text { DHHS (NIAID) } \\
\text { IAVI } \\
\text { Norwegian Aid } \\
\text { US Depart. Of Defense } \\
\text { Foreign Affairs, Ireland } \\
\text { MRC } \\
\text { Department for International Development (DfID) } \\
\text { Centre for AIDS Vaccine Immunology } \\
\text { CONRAD } \\
\text { CDC }\end{array}$ \\
\hline Zimbabwe & $\begin{array}{l}\text { University of California, San Francisco } \\
\text { University of California, Los Angeles }\end{array}$ & & $\begin{array}{l}\text { DHHS (NIAID) } \\
\text { BMGF } \\
\text { Ibis Reproductive Health } \\
\text { Women's Global Health Imperative }\end{array}$ \\
\hline Zambia & $\begin{array}{l}\text { University of Washington } \\
\text { University of Alabama } \\
\text { Dartmouth-Hitchcock Medical Centre }\end{array}$ & Indevus & $\begin{array}{l}\text { BMGF } \\
\text { MRC } \\
\text { DfID } \\
\text { Thrasher Research Fund } \\
\text { DHHS (NIAID, NICHD) }\end{array}$ \\
\hline
\end{tabular}

\section{OTHER RESEARCH (DRUG TRIALS)}

\section{Method}

The researchers used the ClinicalTrials search tool (http://clinicaltrials.gov/) to identify recent/current trials in the fields of HIV/AIDS and TB for each case country. ClinicalTrials is supported by the DHHS and contains details (apart from investment and funding) on all trials in which USA institutions are engaged. The database also records trials undertaken by non-USA institutions and pharmaceutical companies. Whilst the ClinicalTrials database is comprehensive, it is not exhaustive and may not report the activities of private organisations and trials led by European and Asian institutions.

Trials were identified using key words (HIV, AIDS, tuberculosis, TB) and the relevant country name. All trials that were either active or had commenced in the period 1 January 2005 to 31 December 2008 were considered. The search results were manually extracted from the website and assembled in an Excel spread sheet. The information was ordered according to the following categories: sponsor, project title, summary of intervention, start date, end date, URL link, other stakeholders (engaged in the collaboration), principal investigator, the African partner institution, and the African principal investigator. The investigation excluded all trials related to behavioural interventions. The database was then disaggregated between trials in the field of HIV/AIDS, those in TB and those addressing co-infection.

\section{Outcome}

The identified trials reflect the geo-institutional distribution of grants, in terms of the scale and scope of clinical trials in the different case countries. As in the provision of grants, the majority of trials for HIV/AIDS drugs are conducted in South Africa, either through partnerships between northern universities and local universities/institutions or as pharmaceutical driven $R \& D$ projects. A significant number of trials have also been undertaken in Botswana, Kenya and Uganda, though there is limited involvement of pharmaceutical companies in the Kenyan case. Three countries (CAR, Gabon, and Mozambique) have no institutional involvement in clinical HIV/AIDS trials, a status that reflects their weak institutional capacity and the absence of the private sector as partners.

A comparison between HIV/AIDS and TB clinical research projects shows that DHHS institutions are less committed to TB drug research, whilst the major philanthropic bodies seemingly channel their funds through global initiatives (such as the Global Alliance for TB drug development) rather than university driven projects. Pharmaceutical companies have also invested less heavily in drug research in the field of TB. The pool of funders, moreover, is much more limited.

The research outcome confirmed the dominant role of USA universities, as a result of their ability to acquire funds through the DHHS or from philanthropic bodies, in 
advancing commercial research in the case countries. Their dominance is reflected in Tables 6-8, which summaries the lead universities, pharmaceuticals and funders engaged in trials identified in the areas under consideration.

The position of influence held by single Northern institutions and their access to funding for clinical studies is especially noticeable in the case of Botswana (Harvard School of Public Health), Gambia (MRC UK), Kenya (University of Washington), Malawi (University of North Carolina), Uganda (University of Washington and Case Western Reserve) and Zimbabwe (University of California, San Francisco). In the South African case, many of the identified clinical trials are aligned to or led by four universities: WITS, UKZN, UCT and SUN. The comparative strength of these institutions to acquire partnerships and funding is enhanced by the role of the SA MRC and various public sector health institutions which provide an enabling infrastructural environment. The South African institutions are nevertheless still reliant on Northern funding and the requisite partnerships with Northern universities and institutes.

\section{SCIENTIFIC AND INSTITUTIONAL CHALLENGES}

Sub-Sahara Africa faces an immense challenge to reduce the impact of the HIV/AIDS and TB pandemics. Almost one million persons died as a direct result of AIDS in 2007, whilst 22 million were alive and infected with HIV. WHO estimate that at present approximately four million persons require ART, yet less than half of them receive treatment. The number of persons with TB in SSA has steadily increased and now closely approximates the number of persons with advanced HIV infection requiring ART (3.7 million). There is evidence that the rate of the progression of the HIV/AIDS pandemic is slowing. ART has probably contributed towards this achievement, as drugs have become available in resource poor settings. But access to treatment is limited and there are wide disparities in the availability of the needed health care services between urban and rural regions and between countries. Still much effort is required to reduce the rate of transmission. A particularly worrisome aspect of the disease is the rising rate of prevalence among young women (15-24 years), notably in Southern Africa. This apparent failure to empower the youth and instil behavioural responsibility among young adults after more than a decade of campaigns does not bode well for current preventative strategies. A challenge Africa faces, both medically and socially, will be to curb the transmission of HIV among the $41 \%$ of the sub-continent's population that is currently under 15 years old. This concern is justifiable especially now that it seems that an effective HIV vaccine is more remote than originally proposed. Providing universal access to Voluntary Counselling and Testing, ART and microbicides and other measures must form part of any solution.

'Stopping TB' will require a substantial investment in public health care facilities and three scientific interventions: first, the development of affordable and effective point of care diagnostic tests, second, the provision of new drugs (to shorten treatment), and third, the development of a viable vaccine. It is unlikely that these objectives can be achieved in the short-term, given the current level of investment in TB health services and biomedical research towards this disease. Among the millions already infected with HIV and MTB, another challenge will be to prevent the progression of these diseases in co-infected individuals, including progression of latent MTB infection to active disease and similarly the progression of HIV in people with active TB. The scale of the task at hand has been exacerbated by the emergence of MDR and XDR, though it is still too early to gauge the predicted negative impact in terms of morbidity and mortality.

Table 7. TB Clinical Trial Stakeholders, 2005-2008

\begin{tabular}{|c|c|c|c|}
\hline Ethiopia & LSTM & & Thrasher Research Fund \\
\hline Kenya & L'Institut de Recherche pour le Développement & & WHO/EC \\
\hline Senegal & L'Institut de Recherche pour le Développement & & WHO/European Community \\
\hline South Africa & $\begin{array}{l}\text { L’Institut de Recherche pour le Développement } \\
\text { University of Oxford } \\
\text { Johns Hopkins University } \\
\text { Case Western Reserve University }\end{array}$ & $\begin{array}{l}\text { Tibotec } \\
\text { Bayer }\end{array}$ & $\begin{array}{l}\text { WHO/European Community } \\
\text { CDC } \\
\text { Global Alliance for TB Drug Development }\end{array}$ \\
\hline Uganda & $\begin{array}{l}\text { Johns Hopkins University } \\
\text { Case Western Reserve University } \\
\text { University of Texas }\end{array}$ & Bayer & $\begin{array}{l}\text { DHHS (NIAID) } \\
\text { Global Alliance for TB Drug Development } \\
\text { CDC }\end{array}$ \\
\hline
\end{tabular}


Table 8. HIV/AIDS and TB Coinfection Clinical Trial Stakeholders, 2005-2008

\begin{tabular}{|c|c|c|c|}
\hline Country & Universities (Lead) & Pharmaceuticals & Funders \\
\hline Botswana & & & $\begin{array}{l}\text { USAID } \\
\text { CDC }\end{array}$ \\
\hline Malawi & University of California, San Francisco & & DHHS (NIAID) \\
\hline Mozambique & & & $\begin{array}{l}\text { Médecins Sans Frontières (MSF) } \\
\text { French National Agency for Research on AIDS and Viral Hepatitis }\end{array}$ \\
\hline South Africa & $\begin{array}{l}\text { University of Oxford } \\
\text { Case Western Reserve University } \\
\text { Ottawa Health Research Institute } \\
\text { Imperial College London } \\
\text { Johns Hopkins University } \\
\text { LSHTM } \\
\text { NYU School of Medicine } \\
\text { University of California, San Francisco } \\
\text { CAPRISA }\end{array}$ & & $\begin{array}{l}\text { DHHS (NIAID, NHLBI) } \\
\text { Medecins Sans Frontieres } \\
\text { Thrasher Research Fund } \\
\text { MRC } \\
\text { Rockefeller Foundation } \\
\text { Wellcome Trust }\end{array}$ \\
\hline
\end{tabular}

The challenges for scientific research are numerous. Our investigation suggests five areas in which further research and action are required:

- Identify strategies to combine TB and HIV/AIDS programmes to optimise treatment.

- $\quad$ Explore means to improve and sustain the success of ART, through (inter alia) new drug combinations, reducing side effects, improving treatment adherence, monitoring treatment success and investigating new drug targets.

- Prevent the emergence of antiretroviral drug resistance, through (inter alia) surveillance for transmitted and acquired resistance, improved diagnostic tests and studying resistance in non-B subtypes.

- Improve the diagnosis of active TB in HIV-infected patients.

- Identifying, early on, HIV-infected patients at high risk for developing TB.

African institutions can significantly contribute towards addressing these scientific challenges, but only if they receive a continuous and higher injection of funding. South African institutions are well positioned (scientifically) to lead research, having the human capacity to conduct research and benefiting from supportive state institutions. South African universities also benefit from the economic cluster dynamics of having a formidable local pharmaceutical industry that is already engaged in HIV/AIDS and TB drug and vaccine trials. However, the South African state remains a central actor. The current level of state funding through agencies such as the NRF for biomedical research is simply inadequate. In the case of TB, the state would need to treble the current investment in biomedical research to equal the annual investment in R\&D by the Indian Ministry of Science and Technology, a nation that sees research as an opportunity to develop its country.
Research institutions in most, if not all, of the 12 other case countries have no choice but to remain dependent on Northern finance and partnerships. But this dependency can and should be managed in the way that Uganda has pursued the growth of its medical research institutions and allied sectors. Although operating in an LDC context, Ugandan institutions have been able to attract partnerships that enhance their ability to acquire grants, whilst private pharmaceuticals and research organisations/institutions have established research operations in response to the cluster opportunities. The net result has been an accumulation of human, technical and institutional capacity and the establishment of rule systems, including ethics, which allow state of the art research to be conducted effectively. The challenge is thus to turn the dependency on Northern funding and partnerships into a strategic advantage. This is complicated - in some case countries, notably South Africa by the competitiveness among research institutions for grants and partnerships. The competitiveness can also result in a spatial dislocation in the distribution of research expertise. Again in the South Africa case, the bulk of grants for HIV/AIDS biomedical research have been given to institutions in Gauteng and KwaZulu-Natal provinces, whereas the bulk of grants for TB biomedical research have been awarded to institutions in the Western Cape province. The dislocation of research in HIV/AIDS and TB may hinder efforts to advance measures to address co-infection and this has possibly contributed towards the historic 'under-funding' of TB research in the period under consideration.

\section{ACKNOWLEDGEMENTS}

The work presented in this manuscript is derived from the EUCO-Net project funded by the 7th Framework Programme of the European Commission.

\section{REFERENCES}

[1] United Nations Statistics Division. Demographic Yearbook 2006. New York: UN Statistics Division 2006. 
[2] Population Reference Bureau. 2008 World Population Data Sheet. Washington DC, USA: Population Reference Bureau 2008

[3] United Nations Department of Economic and Social Affairs, Population Division. World Population Prospects 2008 Revision. Available from: http://www.un.org/esa/population/unpop.htm (accessed April 09, 2009).

[4] World Health Organization. Global tuberculosis control surveillance, planning, financing: WHO Report 2008. WHO/HTM/TB/2008.393. Geneva: WHO 2008.

[5] National Institute of Communicable Diseases. Provisional laboratory indicators for NHLS and NICD, South Africa, corresponding periods 1 January - 31 December 2007/2008. Communicable Diseases Surveillance Bulletin March 2009; 7(1): 32-3.
[6]

Joint United Nations Programme on HIV/AIDS (UNAIDS). Report on the global HIV/AIDS epidemic 2008: executive summary. UNAIDS/08.27E / JC1511E. Geneva, Spain: UNAIDS 2008.

[7] World Health Organization. World Health Statistics 2008. Geneva, Spain: WHO 2008

[8] Feuer C. Tuberculosis Research and Development: A Critical Analysis, second edition. Treatment Action Group, 2008. Available from: http://www.treatmentactiongroup.org.

[9] HIV Vaccines and Microbicides Resource Tracking Working Group. Sustaining the HIV prevention research agenda: funding for research and development of HIV vaccines, microbicides and other new prevention options, 2000 to 2007. HIV Vaccines and Microbidides Resource Tracking Working Group, 2008. Available from: http://hivresourcetracking.org.

(C) Charman et al.; Licensee Bentham Open.

This is an open access article licensed under the terms of the Creative Commons Attribution Non-Commercial License (http://creativecommons.org/licenses/ by-nc/3.0/) which permits unrestricted, non-commercial use, distribution and reproduction in any medium, provided the work is properly cited. 